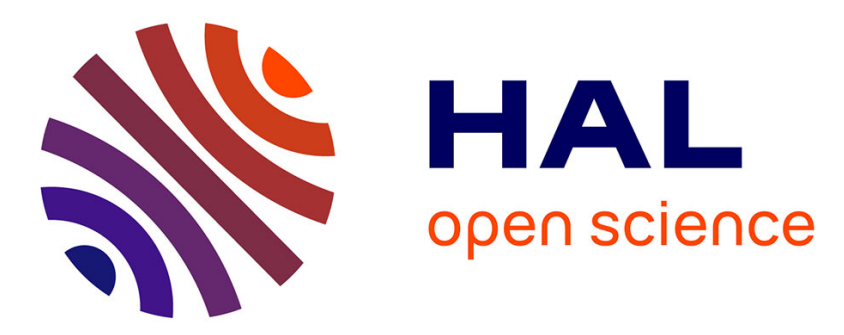

\title{
Geometrical Trends within sequences of Pleistocene marine Terraces: selected examples from California, Peru, Chile and New- Zealand
}

Vincent Regard, Kevin Pedoja, Irene de La Torre, Marianne Saillard, Joaquin Cortés-Aranda, Maëlle Nexer

\section{To cite this version:}

Vincent Regard, Kevin Pedoja, Irene de La Torre, Marianne Saillard, Joaquin Cortés-Aranda, et al.. Geometrical Trends within sequences of Pleistocene marine Terraces: selected examples from California, Peru, Chile and New- Zealand. 2017. hal-01497422

\section{HAL Id: hal-01497422 \\ https://hal.science/hal-01497422}

Preprint submitted on 6 Apr 2017

HAL is a multi-disciplinary open access archive for the deposit and dissemination of scientific research documents, whether they are published or not. The documents may come from teaching and research institutions in France or abroad, or from public or private research centers.
L'archive ouverte pluridisciplinaire HAL, est destinée au dépôt et à la diffusion de documents scientifiques de niveau recherche, publiés ou non, émanant des établissements d'enseignement et de recherche français ou étrangers, des laboratoires publics ou privés. 


\title{
Geometrical Trends Within SEQUenCes of Pleistocene MARINE TERRACES: SELECTED EXAMPLES FROM CALIFORNIA, Peru, Chile ANd NeW- ZEAland
}

\author{
Vincent Regard ${ }^{1,2,3 *}$, Kevin Pedoja ${ }^{4,5,6}$, Irene De La Torre ${ }^{1,2,3}$, Marianne Saillard ${ }^{1,2,3}$, \\ Joaquin Cortés-Aranda ${ }^{7,8}$, Maëlle Nexer ${ }^{4,5,6}$
}

1- Université de Toulouse ; UPS GET, 14 avenue E. Belin, F-31400 Toulouse, France

2- CNRS ; GET ; 14 avenue E. Belin, F-31400, Toulouse, France

3- IRD ; UR 234, GET ; 14 avenue E. Belin, F-31400, Toulouse, France

4- Normandie Univ, France

5- UCBN, M2C, F-14000 Caen, France

6- CNRS, UMR 6143 M2C, F-14000 Caen, France

7- ISTerre, Université de Savoie, CNRS, F-73376 Le Bourget du Lac, France.

8- Departamento de Ciencias de la Tierra, Universidad de Concepción, Concepción, Chile

* corresponding author: vincent.regard@get.omp.eu; Ph: +33 561332645; Fax: +33 561332560

\section{Abstract}

Elevations of the shoreline angles of marine terraces have long been used to infer Pleistocene sea levels and/or uplift rates. We attempt to use morphologic properties of sequences of marine terraces -terrace width and slope- in order to track if these constitute a pattern showing similar alternations at different sites and if this alternation is comparable to the signal from the sea level highstand succession -duration and sea level-for Middle-Late Pleistocene. To do so, we focus on sequences of marine terrace including more than 10 successive strandlines from San Clemente Island and Santa Cruz (both in California, USA). We generated and analyzed 30 topographic profiles in order to confirm the occurrence or lack of each terrace, and to characterize their width and slope. To complement the observation of tenuous trends, we used additional data from previous works at Point Reyes (California, USA), Altos de Talinay (central Chile), San Juan de Marcona (central Peru) and South Taranaki (Northern Island, New Zealand). These additional data strengthen the observations made at San Clemente and Santa Cruz and prove that the most prominent terrace observed is usually carved during the Marine Isotopic Stage 5 (MIS5). Moreover, some terraces appear better expressed than the others: those formed during MIS7, MIS9 plus one of those formed during MIS15, MIS17 or MIS19 highstands. The terraces formed during MIS11 are not preeminent, contrary to what expected from its long highstand duration.

Keywords: Marine terrace; Sea level; Quaternary; Interglacial; San Clemente Island, Santa Cruz, Point Reyes, San Juan de Marcona, Nazca, South Taranaki, altos de Talinay 


\section{Introduction}

Emerged sequences of marine terraces, and others uplifted paleoshores, have proven to be useful tools for estimating local uplift rates (e.g., HENRY et al. 2014; LAJOIE et al. 1991; MELNICK et al. 2009; MUHS 1983; PEDOJA et al. 2006; PEDOJA et al. 2011a; PEDOJA et al. 2011b; PEDOJA et al. 2014; PILLANS 1983; PIRAZZOLI et al. 1993; SAILLARD et al. 2009; SAILLARD et al. 2011; SAILLARD et al. 2012). This estimation is done assuming that a marine terrace is a fossil shoreline, cut/built/constructed at the time of sea level stillstand. The experience tells that sea level highstands in an uplifting context are more prone to produce terraces subsequently fossilized (LAJOIE 1986). Meanwhile, some authors have focused on the development of modern rocky shore platform (CAPLAIN et al. 2011; STEPHENSON \& KIRK 2000a; STEPHENSON \& KIRK 2000b; TRENHAILE 2000), sometimes with inference on marine terrace formation (ANDERSON et al. 1999; TRENHAILE 2002). In the following, we consider marine terraces as uplifted rocky shore platforms devoid of sediments: we will use the term 'uplifted shore platform' or 'shore platform terrace'. Such landforms are backed by a ses-cliff; once fossilized, the 'shoreline angle' is the intersection between the platform and cliff (cf. LAJOIE 1986). The fossil seacliff may be smoothed by erosion following its formation: in this case terms such as 'riser' or 'scarp' may be more appropriate. Interestingly, with the noticeable exception of Bradley \& Griggs (1976)'s and Jara-Muñoz and Melnick (2015)'s works, little has been done to interpret marine terrace morphology in terms of sequential uplift or highstand duration, in spite of evidence of complex highstand sea level history (e.g., JEDOUI et al. 2003; O'LEARY et al. 2013). It is known that the Middle-Late Pleistocene times are characterized by alternations of sea level highstands and lowstands, each being characterized by its duration, its sea level and possibly other parameters like sea temperature, wave agitation, etc. (see for ex. MASSONDELMOTTE et al. 2010; SIDDALL et al. 2006). Thus, a staircase marine terrace sequence may be considered as a 'barcode' with alternating terraces more or less developed in a staircase sequence. A key question about this barcode is whether it is found in different places on Earth and thus may be of global significance. In particular, the absolute elevation above modern sea level of past highstands (odd MIS-marine isotopic stage) is still a matter of debate (CAPUTO 2007; MURRAY-WALLACE \& WOODROFFE 2014). Nevertheless, this barcode, more or less stretched out by tectonics, is morphologically represented by staircase coastal sequence that are extremely common feature at a global scale (LAJOIE 1986; PEDOJA et al. 2014).

We explore the trends in the geometrical properties of terrace morphology; i.e., in terms of width and slope. Indeed, a long-lasting highstand is supposed to leave time for the sea driving processes (waves, tides...) to carve a wide shore platform fossilized as a wide terrace. On the contrary, the following highstand may have provided conditions for important carving too, meanwhile eroding part of previously-formed terraces (effect sometimes called cannibalism). Similarly, a long-lasting highstand with a stable sea level, may produce a low-dip terrace. In the following, we try to extract the most capable periods of shore platform carving (and terrace generation) in terms of producing wider and low dip terraces, asides the erosion of previously-formed ones.

To achieve such geomorphic statistical study on coastal sequences, we favoured sites where: (i) dated shorelines are numerous. Indeed, dating of shorelines older than 200-300 ka (older than marine isotopic stage MIS9) is often a challenge (See for example the review of 
published ages along the Pacific coast of the Central Andes in REGARD et al. 2010); (ii) a good resolution DEM ( $<15 \mathrm{~m})$ is available; and (iii) where the substratum is homogeneous. This latter property ensures that the morphology of the sequence is not dependent on lithology, thus variations in width or slope for the successive terraces are theorically exclusively due to external parameters. We also supposed that at each sea level highstand, the sea level was close (within $10 \mathrm{~m}$ ) to the modern one (as proposed by sea level reconstructions, e.g. SIDDALL et al. 2006), thus ensuring a similar regional paleogeography and wave propagation close to the shore. These conditions are fulfilled at San Clemente Island and Santa Cruz site (California, USA) (Figure 1).

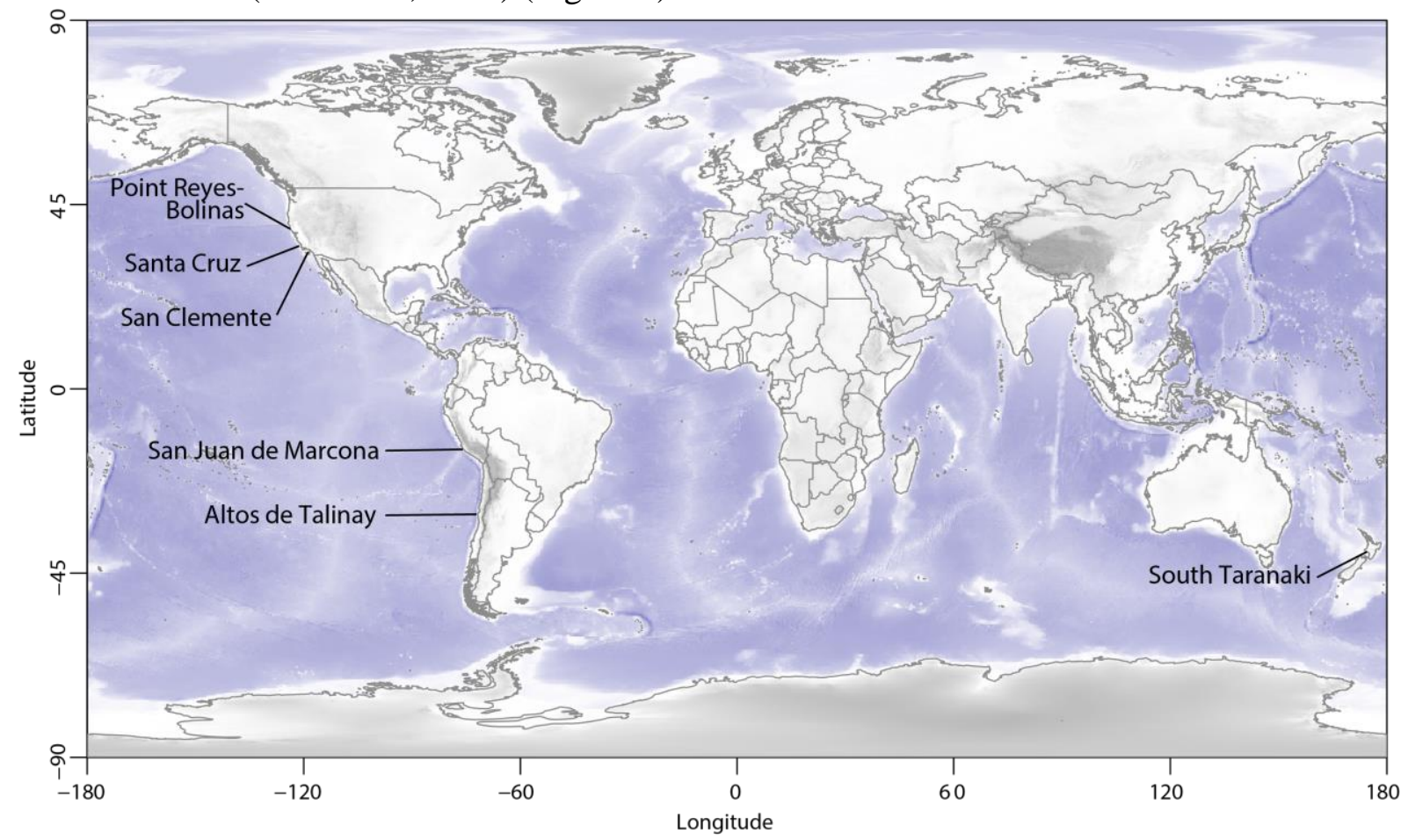

Figure 1. Location of the studied sites.

Afterwards, we compare this dataset with other sites where available -topographic as well as dating- data allow for discussion despite the usual low number of cross sections available. These locations are San Juan de Marcona (Peru), Altos de Talinay (Chile), South Taranaki (New-Zealand) and the Point Reyes peninsula (California, USA) (Figure 1).

Our main result consist in a multi-site analysis of the geometrical trend within well constrained Middle and Late Pleistocene sequences of marine terraces. The correlation of the geometrical trends with the sea level curve led us to spot periods that have been capable to construct terraces wider and of gentle dip. Then, we discussed the common trends (terrace width or slope) in terms of indicators of global processes such as sea level history.

\section{Data and methods}

\subsection{Mapping datasets}

We used three kinds of dataset.

We used the USGS National Elevation Dataset (NED) DEM of 1/3 arc second resolution $(\sim 10 \mathrm{~m})$ (Figure 2). Terrain slope is calculated and a series of topographic cross-sections are derived along which the terraces are identified by their lengths and slopes (Figure 2 and 
Figure 3). San Clemente is undergoing an arid climate favouring good terrace preservation (MUHS 1983). After our own observation, the sequence is more eroded at Santa Cruz site: despite the possibility to track the terrace sequence up to high elevations, it is hard to define the terrace geometry above a couple of hundreds of meters above current sea level. To ensure a good definition of terrace geometry, we often draw discontinuous profiles: in this case, terrace width is not strictly measured on profile but along a straight line, perpendicularly to terrace risers.

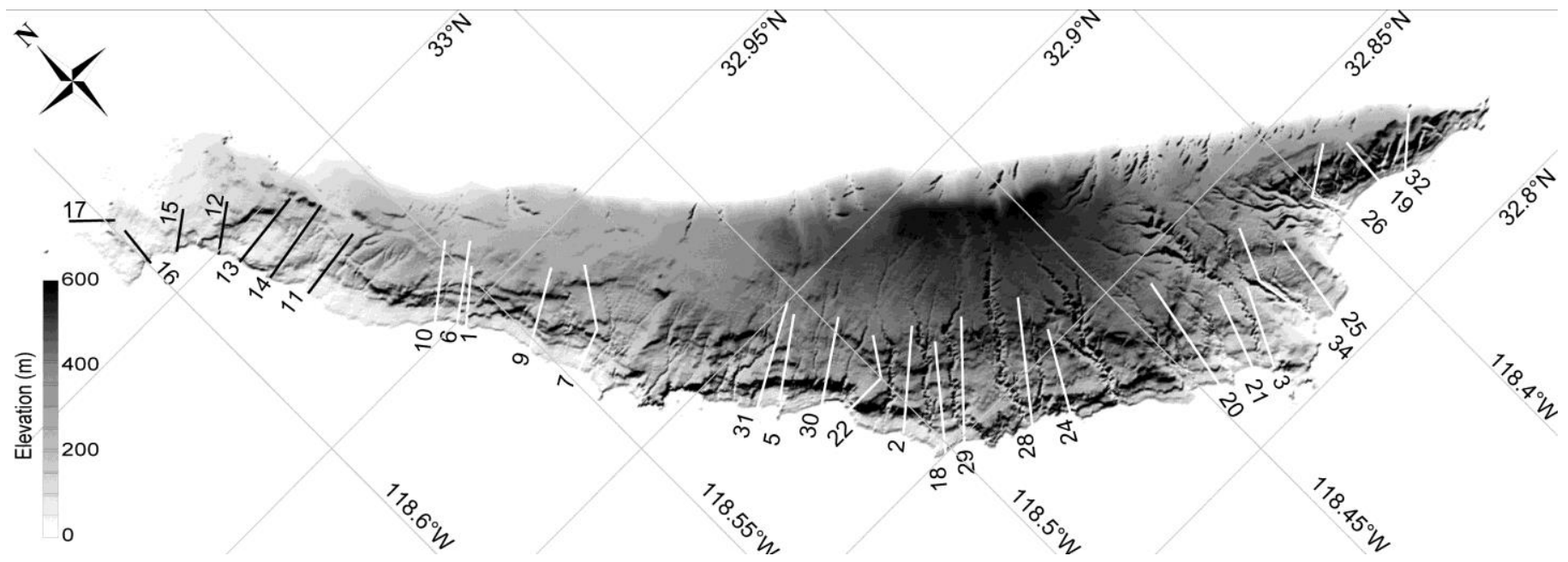

Figure 2. San Clemente Island hillshaded DEM showing the topographic profiles. Note the shadows corresponding to steep slopes highlight the terraces of the southwestern side (facing the ocean) of the island.

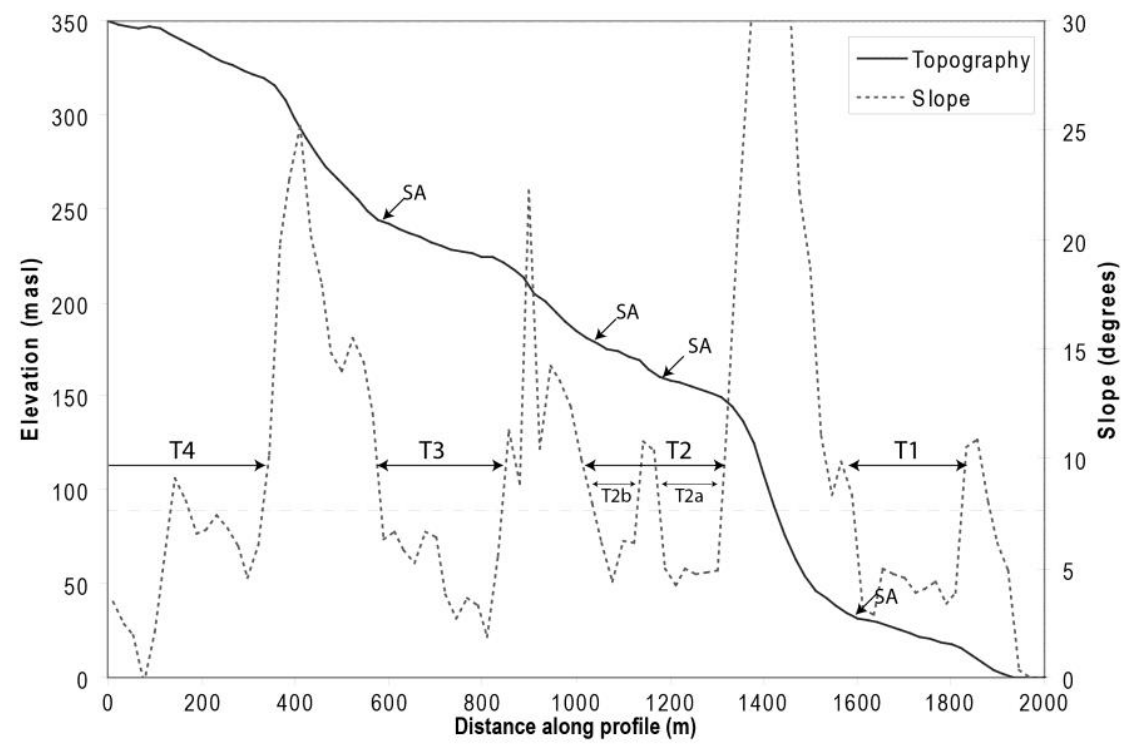

Figure 3. Example of terrace identification (profile n\#2). The continuous line represents the topography, the discontinuous line the slope. Terraces are areas of gentle slope bounded by higher slope areas, usually greater than 15 degrees. The terraces are numbered from bottom to top (T1, T2...). A marine terrace can be compound (i.e., divided into subterraces, as T2a and T2b). Terrace elevation is defined by the elevation of the Shoreline Angle ("SA" at terrace inner edge). 
DEM data rarely provide any information about the possible terrace mantling by continental or marine sedimentation as emphasized by previous works (BRADLEY \& GRIGGS 1976; GROVE et al. 2010; PILLANS 1983; ROSENBLOOM \& ANDERSON 1994). In order to minimize this effect near the terrace shoreline angle or inner edge, but also near the outer edge where the terrace scarp is smoothed, we define terrace extent where slope is low (lower than the arbitrary slope of $15^{\circ}$ that appear to best separate terraces from risers, Figure 3). Such measurements may underestimate the width of each terrace but it ensures that the slopes are not overestimated.

At these two sites (San Clemente and Santa Cruz), we generated 34 and 20 profiles respectively, allowing for statistic computation (the confidence level is fixed to 95\%, 2 $\sigma$ ).

\subsection{Dating, chrono-stratigraphy and uplift rates}

Dating is required in order to propose a local chrono-morphostratigraphy with the correlation of the shoreline angle of the terrace to some highstand in sea level. In the case of uplifted shore platforms few dating methods are available. The most convenient one is cosmogenic dating, providing the time the shore platform was active (see, for example REGARD et al. 2012 on actively eroding shore platform; or SAILLARD et al. 2010 on uplifted terraces). On the other hand, it is possible to approach the uplifted shore platform age through the dating of the sediments over it. See reviews in Regard et al. (2010) and Pedoja et al. (2011b). Such information is usually sparse and age approximation for the other undated terrace levels is necessary. Moreover, many of the available dates are not very accurate, so we use the more accurate data tied to sea level highstands. In the following, we use for past sea levels and interglacial ages those of Siddall et al. (2006), with additional data for MIS (marine isotopic stage) 5a/5c (CUTLER et al. 2003; THOMPSON \& GOLDSTEIN 2006). The assignation of terrace MIS ages allows for calculating the uplift rate (U):

$$
\mathrm{U}=(z t-s l) / t
$$

where $z t$ is the current terrace elevation, $t$ is the MIS time and $s l$ the MIS sea level, at which the terrace is supposed to have formed. As a terrace does not constitute a horizontal reference, the uplift is best recorded by shoreline angle elevation. Usually, workers suppose the uplift rate has little varied in time (e.g., LAJOIE et al. 1991; MARQUARDT et al. 2004; PEDOJA et al. 2006; PIRAZZOLI et al. 1993; REGARD et al. 2010). Indeed, the uplift rate characteristic time (100 kyrs) allows for seismic cycle smoothing and is far less than geodynamic characteristic time (e.g., HENRY et al. 2014). This leads to complete the terrace MIS-age data (cf. Figure 5).

\subsection{Quality indicators of the sequence of marine terraces (presence index and power index)}

Each terrace sequence is different in terms of lithology, wave climate or uplift rate. Additionally, each sequence may be characterized by different terrace slopes and widths. In order to cross-compare the selected sequences, we normalized them to their most frequent terrace, which corresponds to the MIS5 (cf. the dataset presented in this study). Moreover, this is most often the best dated terrace level. This permits a comparison independent on local parameters, but dependant on global parameters like the sea level history, for example.

Most of the terraces observed along the south-western coast of San Clemente Island are morphologically discontinuous. In some places, numerous terraces are lacking within the 
sequence, as observed elsewhere, probably because they have been totally removed posterior to their emplacement by marine erosion (cf. SAILLARD et al. 2009). We suggest that a given terrace should have been totally eroded if the next highstand lasted long enough. In other words, if fossil strandline is lacking, this may be because the next highstands provided conditions strong enough to make it disappear (e.g., by erosion or collapse). This process has not been yet quantified. In order to quantify this phenomenon, we defined two new indices.

(i) The terrace power index $\left(P_{i}\right)$, as the average number of times the next upward terrace is removed during terrace setup:

$P i=n(i+1) / n(i)$

Where $n(i)$ is the number of profiles in which the $\mathrm{i}^{\text {th }}$ terrace is detected. It is expected to provide qualitative information on how strong is the marine erosion during a highstand (i.e. if it is strong enough to remove previously formed shore terraces).

(ii) The presence rate $(\mathrm{Pr})$ is defined as the number of times the terrace is observed divided by the number of times any older terrace is observed. Indeed, if older terraces are found, the terrace must be found. At this stage of study we postulate that if a terrace is missing it relate to its further erosion rather than to the fact it was not carved.

\section{Geometry of Late and Middle Pleistocene sequences of marine terraces}

\subsection{San Clemente, CA, USA}

The sequence is well preserved since the climate is arid and little human occupation (currently a US NAVY base and a marine wild life reserve)(MUHS 1983). The island has a quite linear NW-trend (Figure 2) and is very homogeneous in terms of geology, mostly composed of andesites and dacites (MERIFIELD et al. 1971). San Clemente has long been studied for its well preserved shore platform terrace sequence (>13 terraces) reaching $500 \mathrm{~m}$ in elevation (e.g., CRITTENDEN \& MUHS 1986; LUDWIG et al. 1992; MUHS 1983; MUHS et al. 2002; MUHS \& SZABO 1982) (Figure 2). The faults affecting the island have not been active since the onset of the sequence (MERIFIELD et al. 1971). Dating and correlation to the Pleistocene highstands of each terrace have been performed by Muhs (1983). In addition, good resolution DEM is available $(10 \mathrm{~m})$ from the USGS. The terraces are numbered to follow the numbering used by previous authors (MUHS 1983; MUHS et al. 2002), (Figure 3 and Figure 4).

Dating constraints (radiocarbon, amino-acid racemisation, and U-Th) are available for the terraces T02b, T02a and T05 (MUHS 1983; MUHS et al. 2002). Following these authors T02b and T02a were formed during interstadials MIS (marine isotopic stage) 5a or 5c (85-100 ka) and MIS5e (125 ka; 30.2 $\pm 1.1 \mathrm{~m}$ ), respectively (MUHS 1983; MUHS et al. 2002). The chronostratigraphic interpretation yielded by shell amino-acids from T05 is not straightformward, around 415-575 ka, possibly corresponding to MIS11 (400 ka), MIS13 (480-500 ka) or MIS15 (570 ka). Here, two scenarios lead to a constant uplift rate, depending on whether T05 is assigned to MIS13 or MIS11. On the one hand, MIS13 is closer to the age measured by Muhs (1983) for T05 (415-575 ka, Figure 5). On the other hand, assigning T05 to MIS11 ensures that within the sequence, all the successive interglacials are represented by a terrace (Figure 5). This latter case appears more likely, since MIS11 has been reported to be a long-lasting interglacial, leading to extensive rock shore coastal landforms (BOWEN 2010; 
cf. ORTLIEB et al. 2003; REGARD et al. 2010; SIDDALL et al. 2006). These scenarios imply uplift rates ranging from 0.25 to $0.3 \mathrm{~m} / \mathrm{ka}$ (cf. WARD \& VALENSISE 1996).

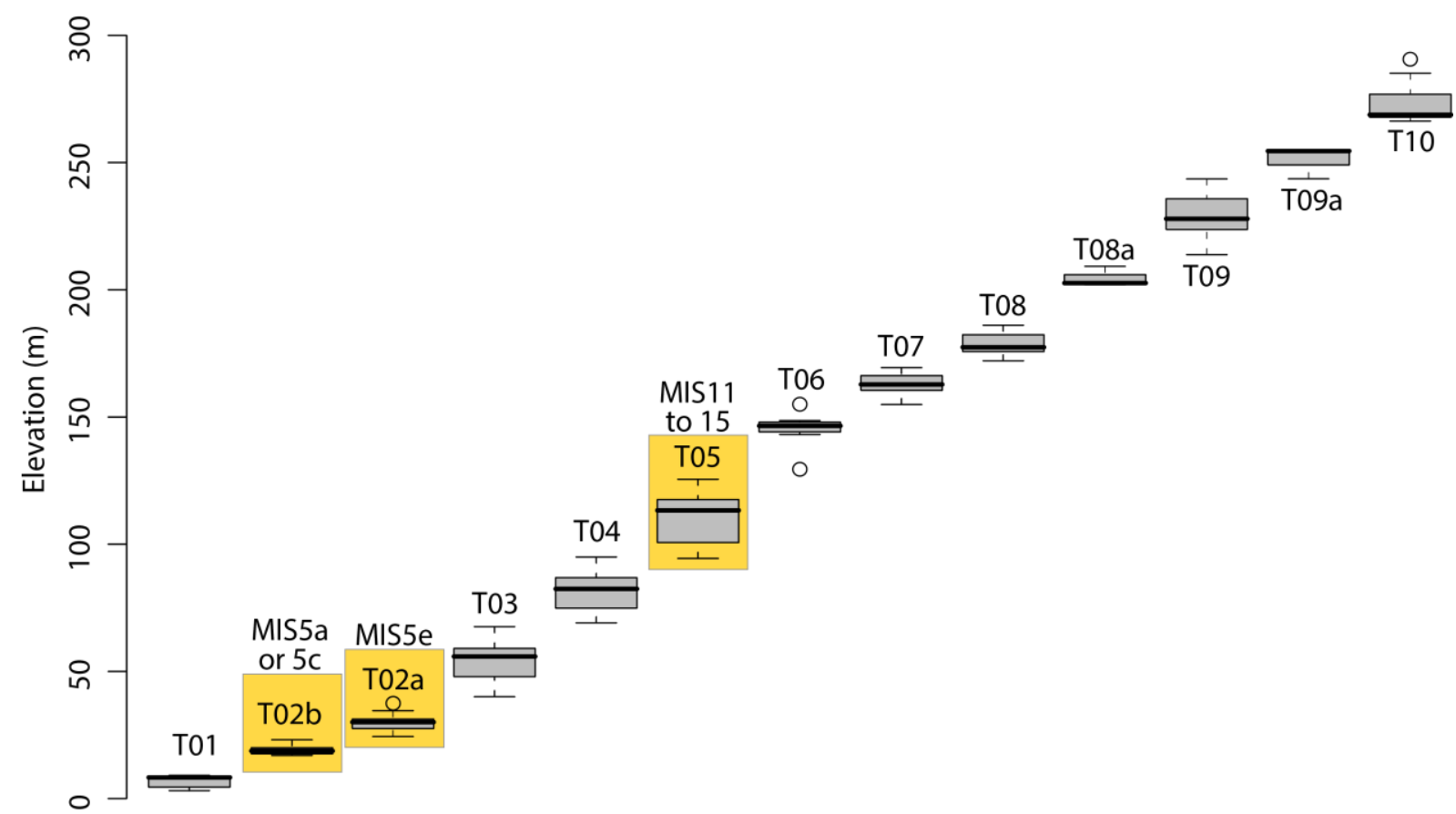

Figure 4. Terrace shoreline angles (cliff toes) elevation in our dataset for San Clemente Island. The numbering is similar to that used by Muhs (1983). Yellow rectangles: age constraints by Muhs (1983) and Muhs et al. (2002).

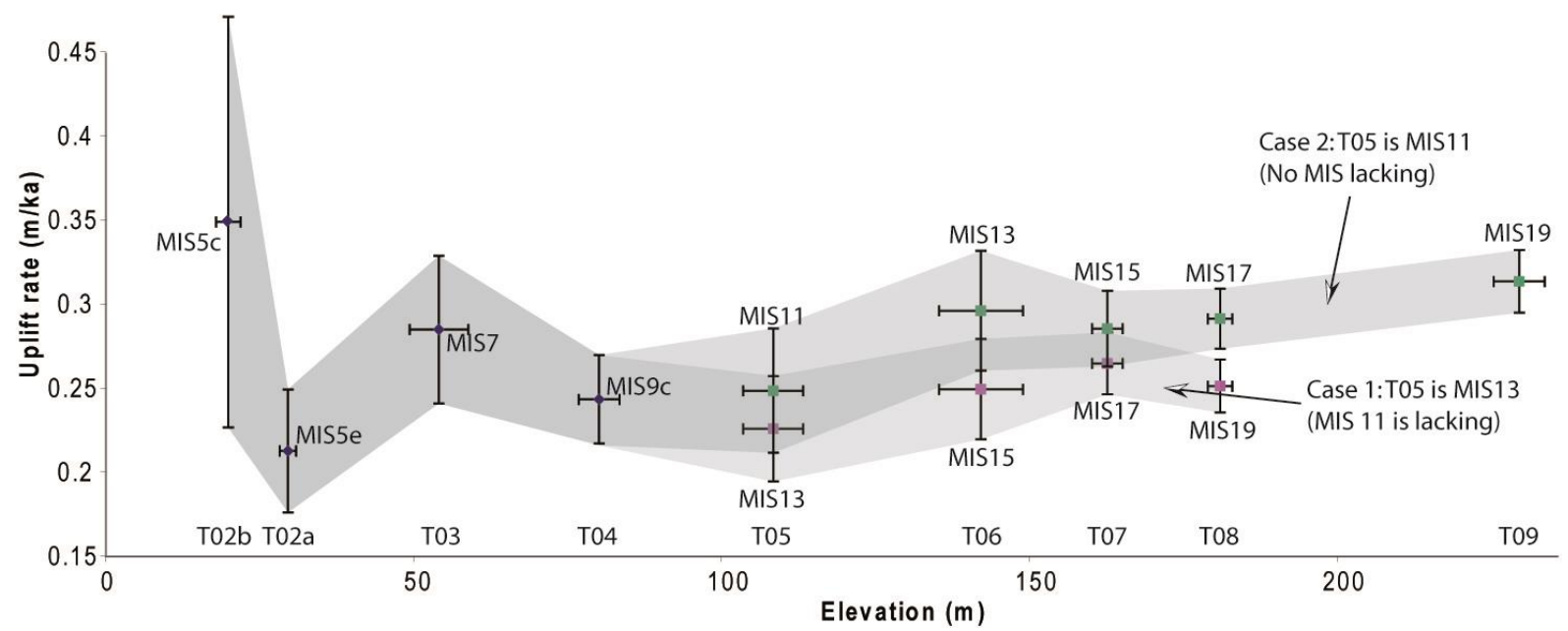

Figure 5. San Clemente Island marine terraces, their elevations and ages inferred for San Clemente Island. 2 scenarios seem acceptable. In the first one, a MIS13 age is inferred for T05, fitting better the dating by Muhs (1983). The second one fits less with dating constraints but no terrace has been removed. Both scenarios imply approximatively constant uplift rates ( 0.25 and $\sim 0.3 \mathrm{~m} / \mathrm{kyr}$, respectively). 


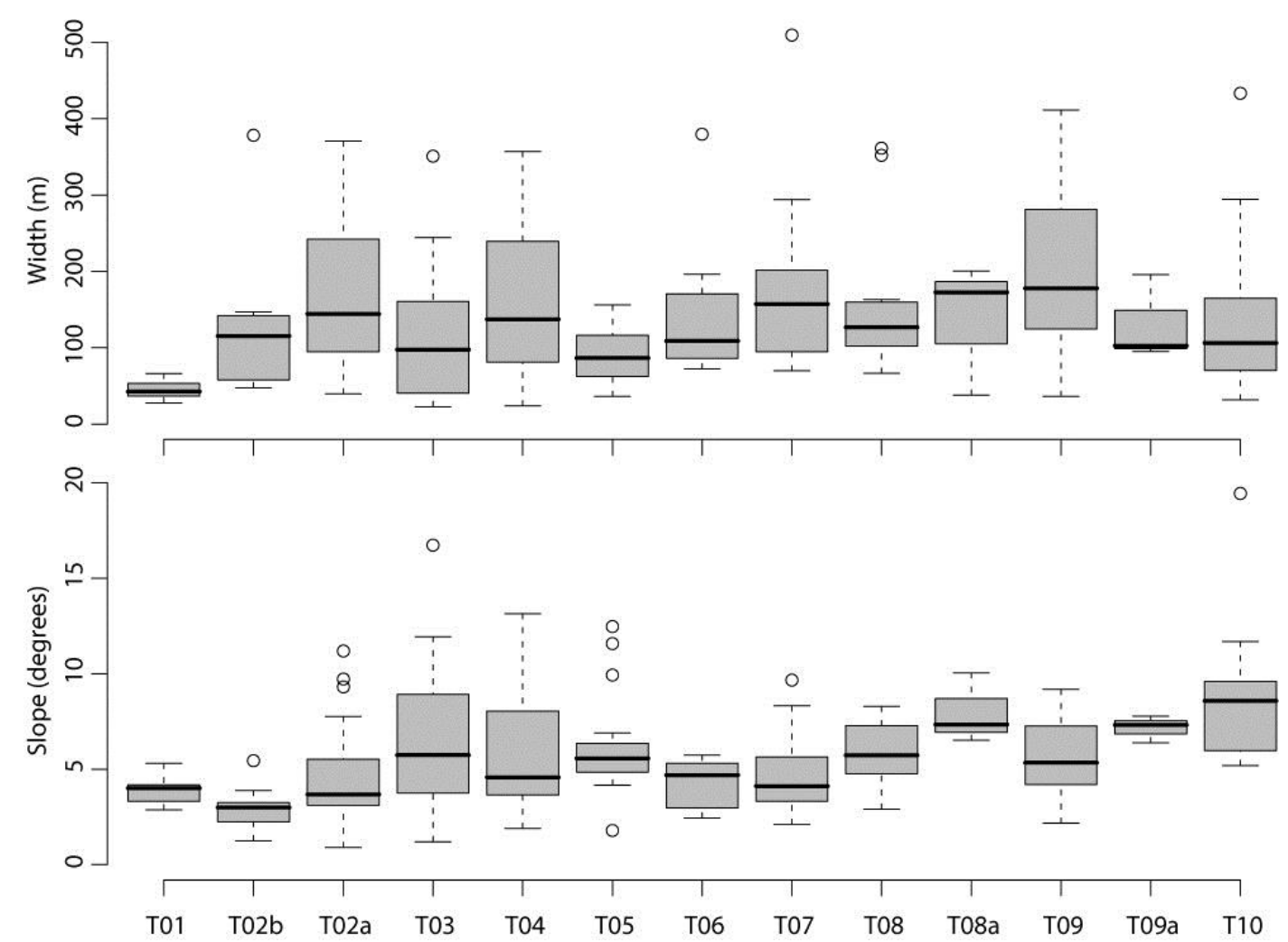

Figure 6. Width and slope distribution for each terrace level in San Clemente.

\begin{tabular}{lccccccccccccc}
\hline Terrace & T01 & T02b & T02a & T03 & T04 & T05 & T06 & T07 & T08 & T08a & T09 & T09a & T10 \\
\hline Number of data & 5 & 11 & 27 & 16 & 16 & 15 & 8 & 15 & 11 & 3 & 17 & 3 & 9 \\
Altitude (m) & $\mathbf{8 . 4}$ & $\mathbf{1 8 . 9}$ & $\mathbf{3 0 . 2}$ & $\mathbf{5 6 . 0}$ & $\mathbf{8 2 . 6}$ & $\mathbf{1 1 3 . 5}$ & $\mathbf{1 4 6 . 8}$ & $\mathbf{1 6 3 . 1}$ & $\mathbf{1 7 7 . 7}$ & $\mathbf{2 0 2 . 9}$ & $\mathbf{2 2 8 . 2}$ & $\mathbf{2 5 4 . 9}$ & $\mathbf{2 6 9 . 2}$ \\
+/- & 2.9 & 1.1 & 1.1 & 4.4 & 4.7 & 6.9 & 2.2 & 2.4 & 3.2 & 3.3 & 4.6 & 5.2 & 4.8 \\
Length (m) & $\mathbf{4 2 . 7}$ & $\mathbf{1 1 5 . 4}$ & $\mathbf{1 4 4 . 3}$ & $\mathbf{9 7 . 6}$ & $\mathbf{1 3 7 . 3}$ & $\mathbf{8 6 . 5}$ & $\mathbf{1 0 9 . 0}$ & $\mathbf{1 5 7 . 2}$ & $\mathbf{1 2 6 . 9}$ & $\mathbf{1 7 2 . 6}$ & $\mathbf{1 7 7 . 8}$ & $\mathbf{1 0 2 . 6}$ & $\mathbf{1 0 6 . 4}$ \\
+/- & 11.7 & 39.9 & 44.8 & 47.4 & 62.5 & 21.9 & 47.2 & 43.7 & 27.4 & 74.1 & 60.0 & 45.9 & 49.7 \\
Slope (degrees) & $\mathbf{4 . 0}$ & $\mathbf{3 . 0}$ & $\mathbf{3 . 7}$ & $\mathbf{5 . 7}$ & $\mathbf{4 . 6}$ & $\mathbf{5 . 6}$ & $\mathbf{4 . 7}$ & $\mathbf{4 . 1}$ & $\mathbf{5 . 7}$ & $\mathbf{7 . 3}$ & $\mathbf{5 . 3}$ & $\mathbf{7 . 3}$ & $\mathbf{8 . 6}$ \\
+/- & 0.6 & 0.5 & 0.7 & 2.0 & 1.7 & 0.6 & 1.3 & 0.9 & 1.2 & 1.6 & 1.2 & 0.6 & 1.9 \\
\hline
\end{tabular}

Table 1. San Clemente Island terrace sequence geometrical data

The data and statistics on the sequence in San Clemente (Table 1) show the width and slope distribution for each terrace (Figure 6). In order to allow for easier comparisons from place to place we normalised the data to similar data of the most relevant terrace, that dating from the MIS5 interglacial (T02b and T02a, Figure 7 and Table 2). Indeed, T02 is the most often detected terrace along our profiles (presence rate of 0.9, Figure 8). The normalisation to T02 (MIS5 terrace) highlights that other terraces are usually narrower (except T09) and have a steeper slope (except T01 and T06, Figure 7) than T02.

\begin{tabular}{lcccccccccc}
\hline & & & & & & & & & & \\
Terrace & T01 & T02 & T03 & T04 & T05 & T06 & T07 & T08 & T09 & T10 \\
\hline Preferred MIS & $\mathbf{3}$ & $\mathbf{5}$ & $\mathbf{7}$ & $\mathbf{9}$ & $\mathbf{1 1}$ & $\mathbf{1 3}$ & $\mathbf{1 5}$ & $\mathbf{1 7}$ & $\mathbf{1 9}$ & $\mathbf{2 1}$ \\
\hline Number of data & 5 & 29 & 14 & 16 & 13 & 7 & 15 & 12 & 16 & 9 \\
Normalised length & $\mathbf{0 . 2}$ & $\mathbf{1}$ & $\mathbf{0 . 4}$ & $\mathbf{0 . 8}$ & $\mathbf{0 . 4}$ & $\mathbf{0 . 5}$ & $\mathbf{0 . 8}$ & $\mathbf{0 . 6}$ & $\mathbf{1 . 0}$ & $\mathbf{0 . 4}$ \\
+-- & 0.0 & & 0.2 & 0.5 & 0.2 & 0.3 & 0.3 & 0.3 & 0.6 & 0.8 \\
Normalised slope & $\mathbf{0 . 9}$ & $\mathbf{1}$ & $\mathbf{2 . 1}$ & $\mathbf{1 . 2}$ & $\mathbf{1 . 5}$ & $\mathbf{0 . 7}$ & $\mathbf{1 . 0}$ & $\mathbf{1 . 7}$ & $\mathbf{1 . 2}$ & $\mathbf{2 . 1}$ \\
+ +- & 0.2 & & 0.6 & 0.4 & 0.2 & 0.2 & 0.2 & 0.5 & 0.4 & 0.7 \\
\hline
\end{tabular}

Table 2. San Clemente Island marine terrace average data normalised to T02 (grouped T02b and T02a). 


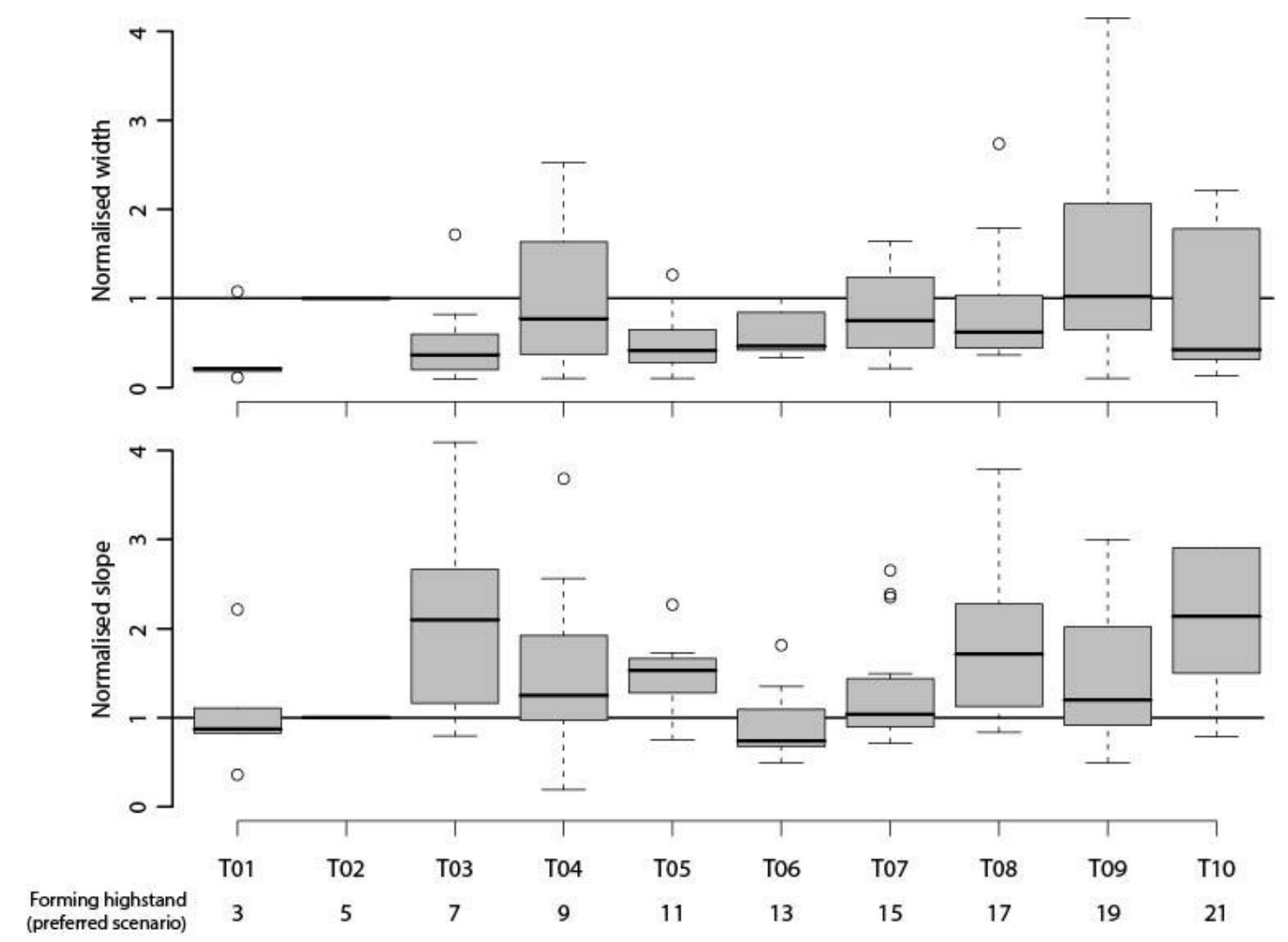

Figure 7. Width and slope distribution for each one of the terrace levels in San Clemente, normalised to terrace T02 (corresponding to the last interglacial). Sub-terraces (eg., T08 and T08a) are grouped.

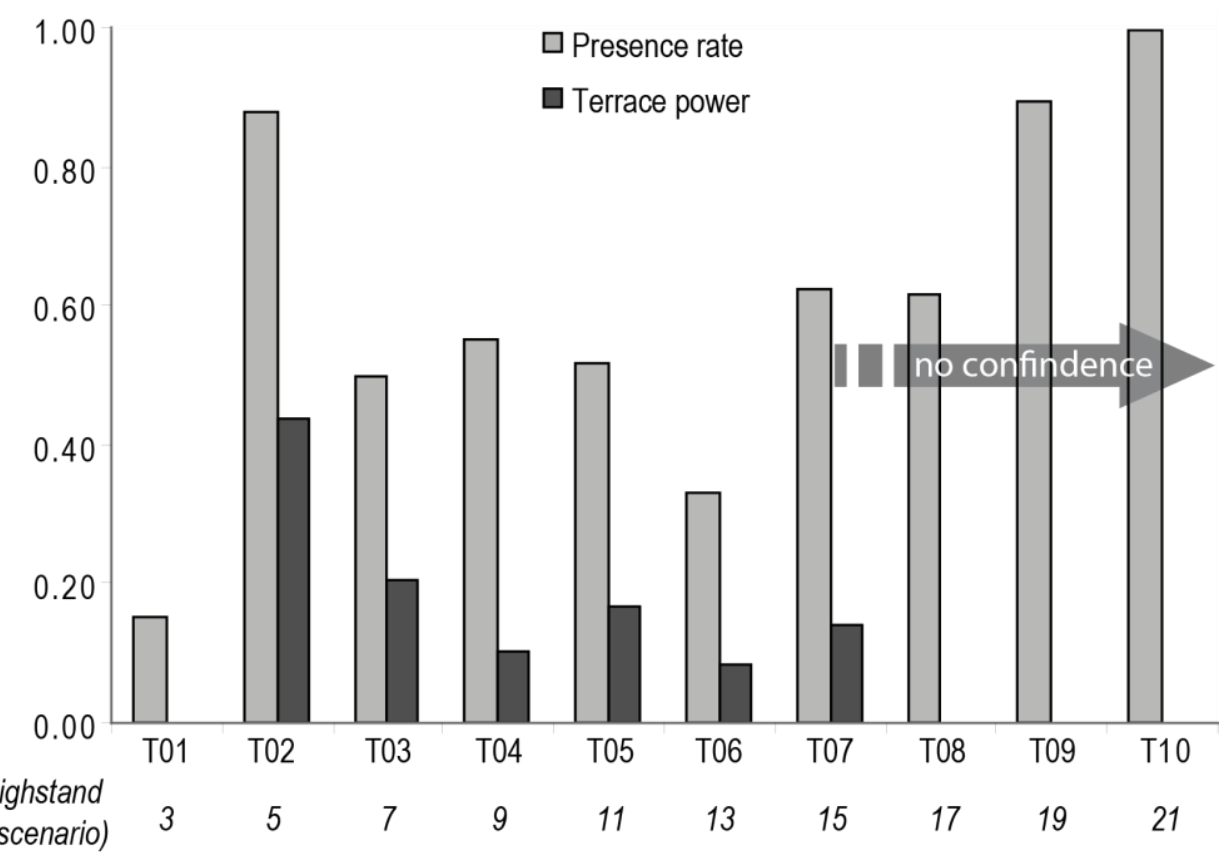

Figure 8. Presence and power indexes of the terraces forming the San Clemente sequences. As written in text the confidence is lost for highest terraces in the sequence.

The Figure 8 shows the presence and power index (respectively $\mathrm{Pr}$ and $\mathrm{Pi}$ ) of the terraces. The above defined presence rate $P r$ of a terrace takes only into account profiles for which more elevated terraces are observed. As such, high presence rates, like those of terraces 
overlooking T07, may be artefacts because they are close to the upward sequence boundary. The same limitation occurs for the power index, also dependant on observation of overlooking terraces. Nevertheless, analysing only terraces T01 to T07, we observed that T02 (MIS5) is far more prominent than the others. T03 (MIS7), T04 (MIS9) and T05 (MIS11 or MIS13) are relatively equivalent in terms of width, and are better marked in the topography than T06 (MIS13 or MIS15). T07 (MIS15 or MIS17) again appears to be more prominent than T06. Finally, T01 is only detected when T02 is present within the sequence (e.g., its power index $P i$ is 0 , Figure 8).

Geometry of the San Clemente sequence of marine terraces reveals the following trends: (i) the terrace allocated to the last interglacial (ie. MIS5 terrace, T02) is wider, flatter and more frequent than the others terraces within the sequences. (ii) The lowermost terrace, which is not always observed nor well marked, could correspond either to to MIS3 or MIS1 (Holocene).

\begin{tabular}{|c|c|c|c|c|c|c|c|c|c|c|c|c|c|c|c|c|c|}
\hline \multirow[b]{2}{*}{ Terrace } & \multirow{2}{*}{$\begin{array}{l}\text { Mean } \\
\text { inner } \\
\text { edge } \\
\text { elevation } \\
\text { (m) }\end{array}$} & \multirow[b]{2}{*}{$\begin{array}{l}\text { Number } \\
\text { of data }\end{array}$} & \multirow[b]{2}{*}{$\begin{array}{l}\text { Age * } \\
\text { (ka) }\end{array}$} & \multicolumn{7}{|c|}{ Option 1} & \multicolumn{7}{|c|}{ Option 2} \\
\hline & & & & MIS & $\begin{array}{l}\text { MIS } \\
\text { age } \\
\text { (ka) }\end{array}$ & $+/-$ & $\begin{array}{l}\text { Sea } \\
\text { level } \\
\text { (m) }\end{array}$ & $+/-$ & $\begin{array}{l}\text { Uplift } \\
\text { rate } \\
\text { (m/ka) }\end{array}$ & $+/-$ & MIS & $\begin{array}{l}\text { MIS } \\
\text { age } \\
\text { (ka) }\end{array}$ & $+/-$ & $\begin{array}{l}\text { Sea } \\
\text { level } \\
\text { (m) }\end{array}$ & $+/-$ & $\begin{array}{l}\text { Uplift } \\
\text { rate } \\
\text { (m/ka) }\end{array}$ & $+/-$ \\
\hline $01 a$ & 30 & 15 & & & & & & & & & 3 & 40 & 5 & -60 & 10 & 1.97 & 0.35 \\
\hline $01 b$ & 71 & 15 & 65 & 3 & 53 & 7 & -60 & 20 & 2.47 & 0.61 & 3 & 53 & 7 & -60 & 20 & 2.23 & 0.49 \\
\hline 2 & 103 & 14 & 91 & $5 a$ & 85 & 5 & -15 & 10 & 1.39 & 0.20 & $5 a$ & 85 & 5 & -15 & 10 & 1.33 & 0.14 \\
\hline 3 & 135 & 8 & 137 & $5 c$ & 100 & 7 & -15 & 3 & 1.50 & 0.15 & $5 c$ & 100 & 7 & -15 & 3 & 1.53 & 0.11 \\
\hline 4 & 181 & 5 & 139 & $5 e$ & 125 & 7 & 0 & 3 & 1.45 & 0.11 & $5 e$ & 125 & 7 & 0 & 3 & 1.40 & 0.09 \\
\hline $5 a$ & 202 & 1 & & $7 a$ & 190 & 7 & 0 & 3 & 1.06 & 0.04 & $7 a$ & 190 & 7 & 0 & 3 & 1.15 & 0.05 \\
\hline $5 b$ & 222 & 5 & 226 & $7 a$ & 190 & 7 & 0 & 3 & 1.17 & 0.08 & $7 a$ & 190 & 7 & 0 & 3 & 1.15 & 0.05 \\
\hline 6 & 248 & 4 & & $7 c$ & 210 & 5 & -10 & 5 & 1.23 & 0.05 & $7 c$ & 210 & 5 & -10 & 5 & 1.27 & 0.04 \\
\hline 7 & 296 & 3 & & $7 e$ & 225 & 7 & 0 & 3 & 1.32 & 0.14 & $7 e$ & 225 & 7 & 0 & 3 & 1.32 & 0.04 \\
\hline 8 & 346 & 2 & & $9 a$ & 280 & 6 & 2 & 5 & 1.23 & 0.06 & $8 c$ & 280 & 6 & -30 & 15 & 1.31 & 0.07 \\
\hline 9 & 378 & 4 & & $9 c$ & 321 & 6 & 8 & 10 & 1.15 & 0.06 & $9 a$ & 315 & 5 & -10 & 5 & 1.23 & 0.04 \\
\hline 10 & 425 & 2 & & 11 & 404 & 6 & 8 & 10 & 1.03 & 0.05 & $9 c$ & 331 & 6 & 8 & 10 & 1.24 & 0.04 \\
\hline $11 a$ & 441 & 2 & & 13 & 480 & 10 & 0 & 10 & 0.92 & 0.03 & $11 a$ & 380 & 10 & -30 & 15 & 1.28 & 0.06 \\
\hline $11 b$ & 449 & 1 & & 13 & 480 & 10 & 0 & 10 & 0.94 & 0.03 & $11 a$ & 380 & 10 & -30 & 15 & 1.28 & 0.06 \\
\hline 12 & 486 & 2 & & 13 & 500 & 10 & 0 & 10 & 0.97 & 0.03 & $11 \mathrm{c}$ & 404 & 6 & 8 & 10 & 1.20 & 0.03 \\
\hline 13 & 548 & 1 & & 15 & 570 & 10 & 0 & 10 & 0.96 & 0.02 & 13 & 480 & 10 & 0 & 10 & 1.14 & 0.05 \\
\hline
\end{tabular}

Table 3. Santa Cruz Terrace inner edge elevations and ages assigned from dating constraints and morphostratigraphy. The age column comes from the work of PERG et al. (2001) and discussion about it (BROWN \& BOURLES 2002; PERG et al. 2002).

\subsection{Santa Cruz, CA, USA}




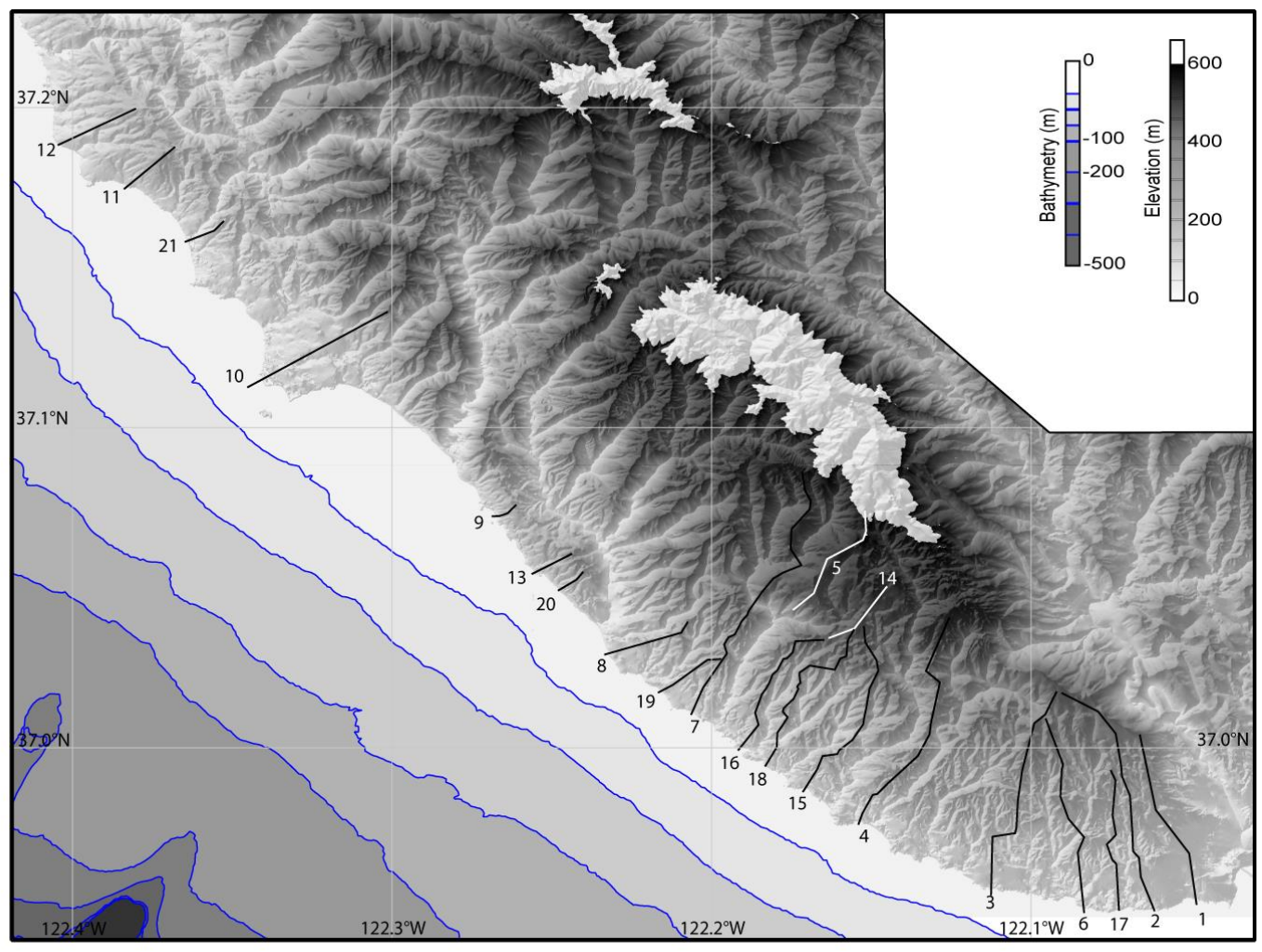

Figure 9a. Santa Cruz hillshaded DEM. The topographic profiles used are shown and numbered. Note that, contrary to San Clemente, the terraces are not clearly visible because of higher degradation (see Anderson et al. 1999).

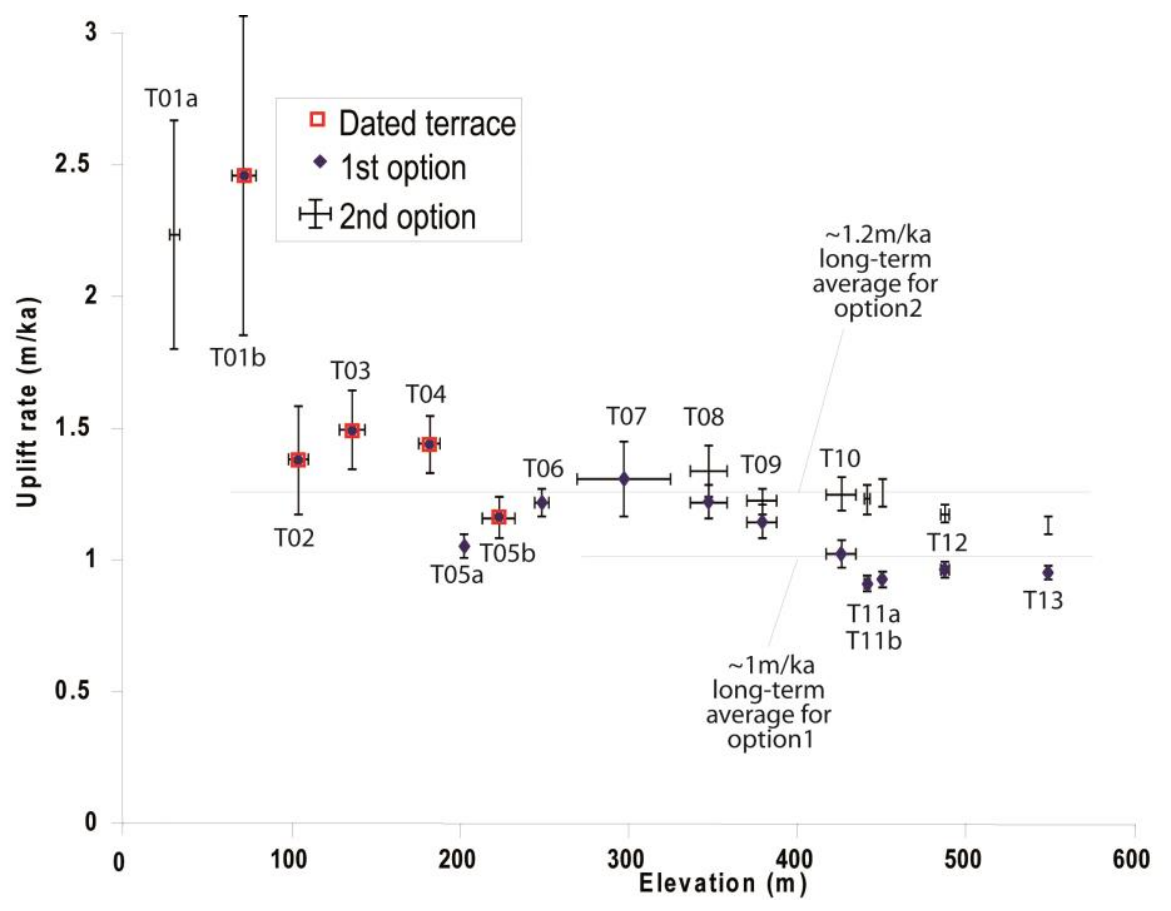

Figure 9b. Terrace elevation and uplift rates for Santa Cruz. Terrace ages are available for terraces T01b to T05, indicating MIS3, MIS5a, MIS5c, MIS5e and MIS7 periods of formation (PERG et al. 2001). See Table 3. 
Next to Santa Cruz (California), a sequence of 8 marine terraces reaching $230 \mathrm{~m}$ in elevation, is carved into Miocene mudstone and fine-grained sandstone lying over a core of metamorphic and plutonic rocks (ALEXANDER 1953; BRADLEY \& GRIGGS 1976; BRANNER et al. 1909; LAWSON 1893; PAGE \& HOLMES 1945; RODE 1930). The successive terraces were named from bottom to top Davenport, Highway 1, Greyhound, Cement, Western, Wilder, Blackrock, and Quarry, and are overlooked by some undefined "upper terraces" (BRADLEY \& GRIGGS 1976). Based on U-series (BRADLEY \& ADDICOTT 1968) and amino acid dating (KENNEDY et al. 1977) of the lowermost standing terrace and its allocation to the last interglacial maximum (MIS5e), BRADLEY \& GRIGGS (1976) correlated the terraces Greyhound to Quarry to Pleistocene highstands since 1.2 Ma. More recently, PERG et al. (2001) through ${ }^{10} \mathrm{Be}$ cosmogenic nuclide dating (Table 3) revised the chronostratigraphy of five of the terraces composing the seuences. They numbered these terraces from 1 to 5 (bottom to top), likely dating from MIS3, MIS5a, MIS5c, MIS5e (181m) and MIS7, respectively. They correspond to Highway 1, Western, Wilder, Blackrock, and Quarry of BRADLEY \& GRIGGS (1976). Such chrono-stratigraphic interpretation implies uplift rates of about $1.1 \mathrm{~mm} / \mathrm{yr}$.
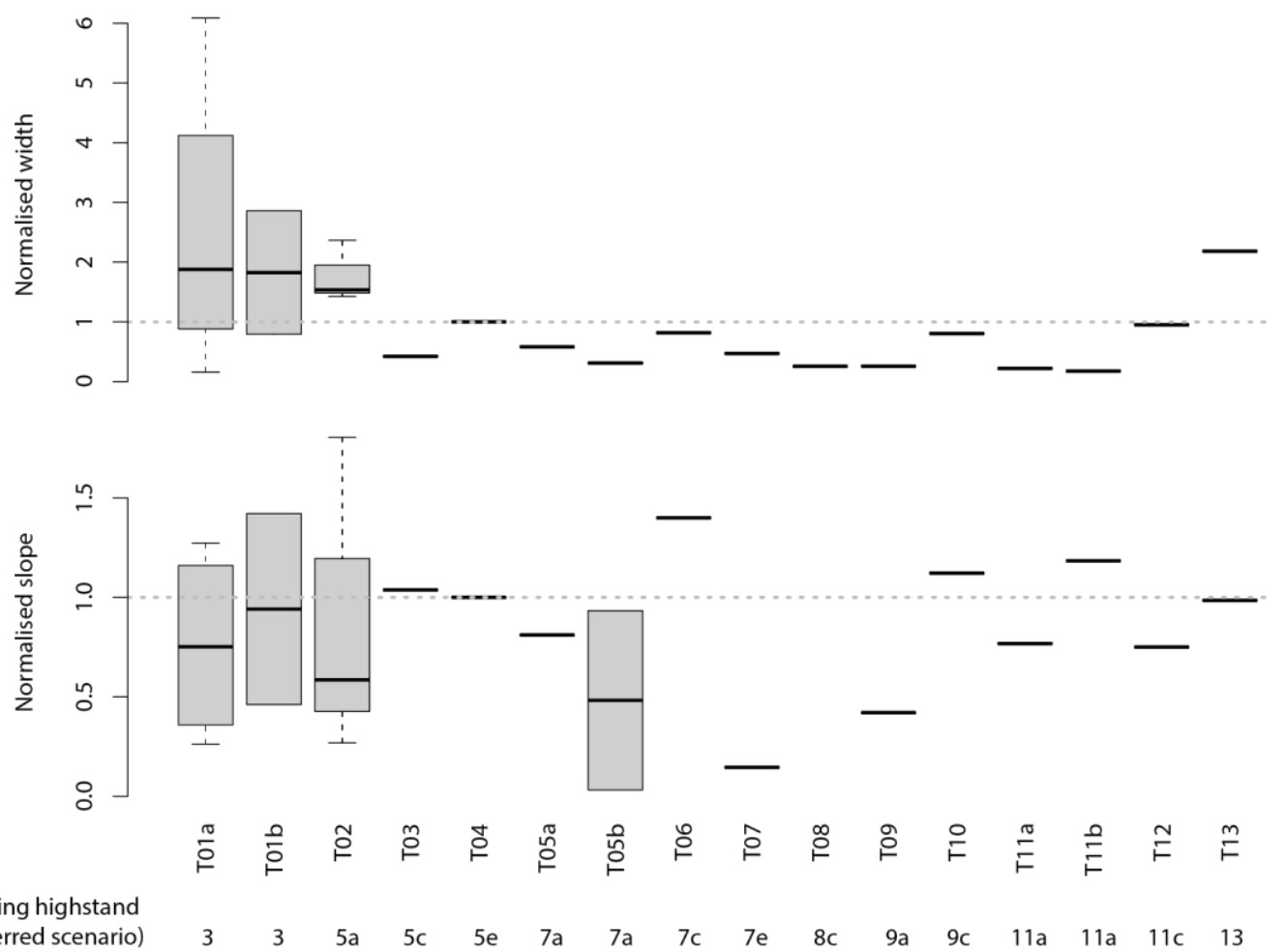

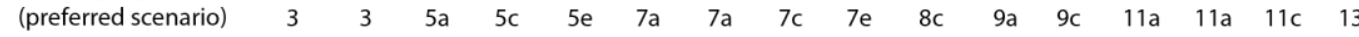

Figure 10. Width and slope of Santa Cruz terraces, normalised to T04.

We extracted 21 topographic profiles and found terraces up to $550 \mathrm{~m}$; i.e., up to T13 (as in PERG et al. 2001) (Figure 9a; Table 3). The data show the terrace record is much subtle than on San Clemente Island as it allows discriminating the marine isotopic sub-stages. For example the substage of MIS5 (i.e., MIS5a, c, e) are morphologically represented by successive, distinct terrace, contrarily to San Clemente. This probably comes from a greater uplift rate than on San Clemente Island (1-1.2 m/ka instead of $0.35 \mathrm{~m} / \mathrm{ka})$, that helps discriminating terrace morphological levels (cf. CAPUTO 2007). For the terraces higher than T5 which is allocated to MIS7a, we extrapolated the uplift rates determined on low standing 
terrace to propose a possible age. Two options are possible, they differ for the higher most terraces, depending on the allocation of T08 to MIS9 or MIS8 (scenarios 1 and 2, respectively, Table 3 and Figure 9b). The one we prefer (option 2) ensures a constant uplift rate of $\sim 1.2 \mathrm{~m} / \mathrm{ka}$, except for the lowermost terraces. In turn, it implies a terrace formed during a glacial stage highstand (MIS8c, option 2 of Table 3) as theoretically proposed by CAPUTO (2007). Thus, the uppermost shoreline we detected through remote sensing would be 480 ka-old (MIS13). The average terrace width and slope are drawn in Figure 10; the values normalised to MIS5 (terraces T02 to T04) are shown on Figure 11. Presence (Pr) and power $(P i)$ indexes are of little use: the terrace sequence is always complete, except terraces T02-T04 that are sometimes lacking.

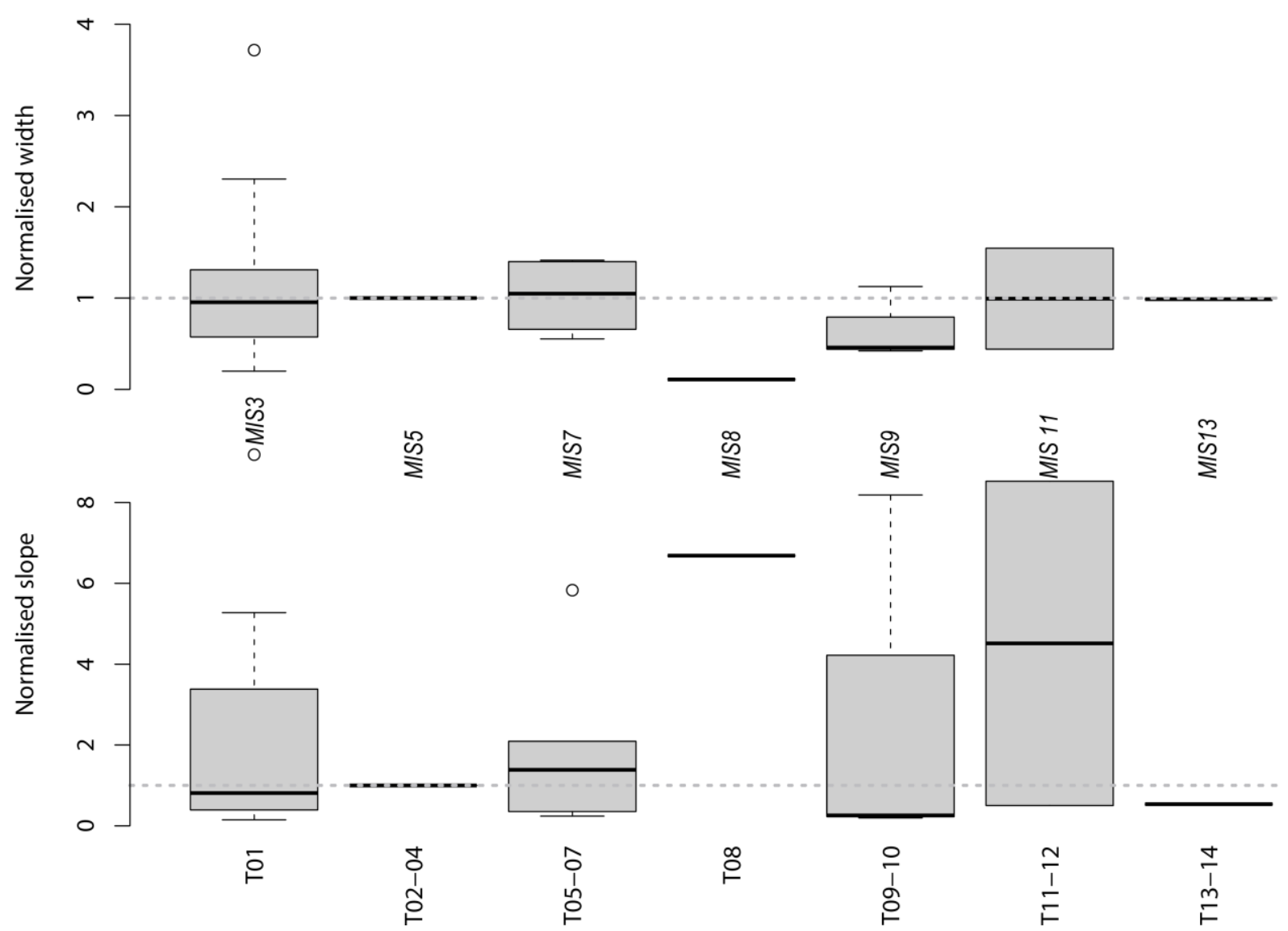

Figure 11. Similarly as Figure 10width and slope of Santa Cruz terraces, but the terraces allocated to the same highstand are grouped and normalised to MIS5. Note that T08 in this interglacial allocation corresponds probably to a glacial highstand (MIS8).

\section{Discussion}

\subsection{Meaning of the width and slope of successive terraces within a sequence}

\subsubsection{Trends highlighted by San Clemente and Santa Cruz}

The data for slope and width for the terraces from the sequences in San Clemente Island and Santa Cruz are summarized in Figure 12. In addition, Figure 8 represents the presence and power indexes for the terraces composing the sequence on San Clemente Island. First, it 
is important to mention that at these two sites, the terrace associated to the MIS5 highstand are by far the most often observed. This is a posteriori justification for our choice of using it as reference. Moreover, its power ( $P i$, only informative for San Clemente) indicates that during last interglacial maximum (MIS5 highstand, i.e., time of the formation of the T02 terrace), previously formed marine terraces must have been eroded. Then, the slope and width figure is more complete up to the terrace allocated to MIS13. Indeed, highstands older than MIS13 are only documented within the San Clemente sequence. That said, the slope figure indicates that terraces allocated to MIS3, MIS9, MIS13, MIS15 and MIS19 have dips comparable to MIS5 terraces. The dips of the terraces allocated to MIS7, MIS11, MIS17, and MIS21 are higher.
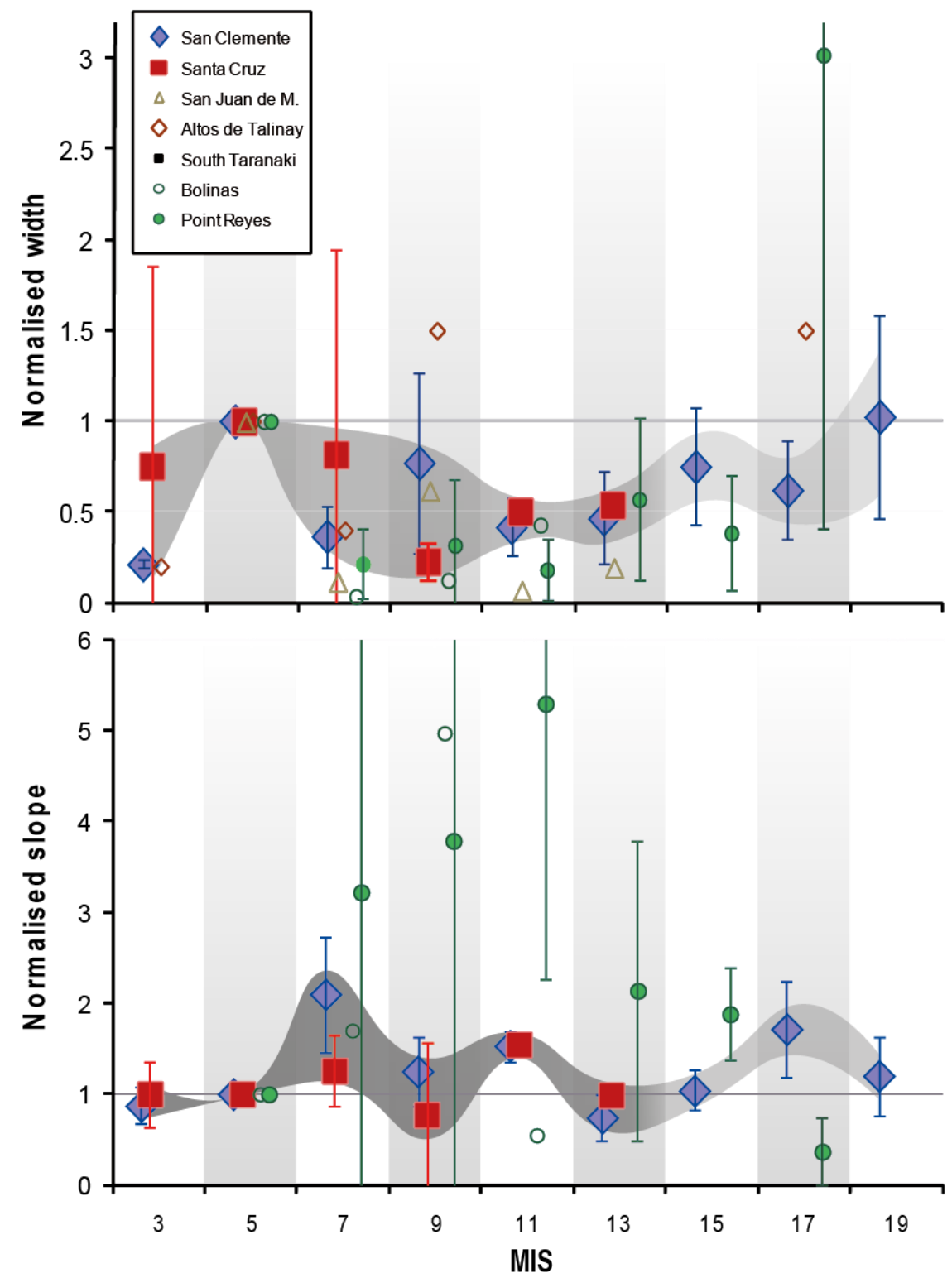

Figure 12. Terrace widths and slopes normalised to that of the MIS5 terrace for the sites described in the text. The numerous data used for San Clemente and Santa Cruz allow the evaluation of error bars; the grey area highlights the trend they describe. There is no slope evaluation for Altos de Talinay. See text for discussion. 
The correlation between the age of the highstand responsible for the carving of the terrace and the width of the last one is important: MIS3 terrace is narrow and moreover often absent (Figure 8). Terraces of MIS7 and 9 are a little bit narrower than MIS5 ones, meanwhile MIS9 is one with the highest presence rate (T04 in Figure 8). MIS11 terrace is quite narrow but often present (T05 in Figure 8), what differs from MIS13 terrace (T06 in Figure 8), which is narrow and rarely expressed in the landscape. Older terraces than MIS13 have not been observed in Santa Cruz. Within the San Clemente sequences, MIS15 and 19 terraces are generally wider than previous ones.

\subsubsection{Comparison with other sites}

Other coasts on Earth display sites for comparison with San Clemente and Santa Cruz. Unfortunately, the data is much less extensive and often consists in one single profile, thus less confident. Hence we present here these sites for comparison.

\subsubsection{The Point Reyes and Bolinas area, CA, USA}

Point Reyes is a peninsula separated from mainland California by the San Andreas Fault's continuation north of San Francisco (Figure 1). McCULLOCH (1989) showed that the Point Reyes peninsula is part of the eastern margin of the offshore Bodega Basin, where a thick sequence of mostly marine Cenozoic sedimentary rocks overlie granitic and metamorphic basement of the Salinian terrane (GROVE et al. 2010).

At least 7 marine terraces are present there and cut into the marine sedimentary rocks, at two sites. Terrace geometry (width and difference in elevation between the inner and outer edges) is reported by GROVE et al. (2010). GROVE et al. (2010) proposed four profiles where the coastline is looking westward (Point Reyes); and one profile at the southern end of the peninsula (Bolinas). At terrace inner edges, the sediment thickness is measured (or evaluated) as precisely as possible. Grove et al. (2010) performed 5 luminescence dating. Two samples, PR-4 and PR-5, are disconnected from the terraces. PR-4 (103 m) shows a scatter in the ages obtained and is not reliable. PR-5 $(85 \mathrm{~m})$ is probably correlated to highstand during MIS5a ( $~ 80 \mathrm{ka})$. Two ages come from Bolinas; they have been attributed, despite important scatter, to MIS4 (PR-1, $50 \mathrm{~m}, \sim 65 \mathrm{ka}$ ) and MIS5a (PR-2, $64 \mathrm{~m}, \sim 80 \mathrm{ka}$ ). The last one sampled from Point Reyes terrace area, suffer also important scattering and has been tentatively related to MIS3 (PR-3, $6 \mathrm{~m}, \sim 45 \mathrm{ka}$ ).

Taking into account obtained ages, GROVE et al. (2010) established local chronostratiraphy and estimated different uplift rates; they are on the order of $0.2-0.4 \mathrm{~mm} / \mathrm{y}$ and $\sim 1 \mathrm{~mm} / \mathrm{y}$, respectively, at Point Reyes and Bolinas. Both sequences are recorded up to $250 \mathrm{~m}$ above sea-level. Consequently, if we consider a constant uplift rate (which may be critical, as discussed earlier), the uppermost terrace age is evaluated to be $\sim 700 \mathrm{ka}$ and $\sim 330$ ka, respectively, at Point Reyes and Bolinas.

We made some adjustments in the above-mentioned morphostratigraphy, keeping the constraints from the work by GROVE et al. (2010). First, uplift rates have been re-calculated with the parameters of the sea-level used all along the present study (cf. Table 4). Second, we found that attributing only one terrace by highstand (odd MIS) appears easier to understand. It usually ensures continuous uplift with little variations in uplift rates. This leads us to relate GROVE et al (2010)'s terrace 3 to MIS5e (39 m in Point Reyes and $87 \mathrm{~m}$ in Bolinas) and terrace 4 to MIS7, except at Bolinas, where the four terraces are related to odd MIS $(5,7,9$ 
and 11) (Table 4). It is intriguing that at Point Reyes the MIS5e terrace is not well developed. This does not introduce bias as we work with the entire MIS5 group; this ensures that erroneous attribution to one of the MIS5 substage (MIS5a, MIS5c or MIS5e) would not change our conclusions. The importance of error reported in Figure 12 comes from the low number of data and their dispersion.

\begin{tabular}{|c|c|c|c|c|c|c|c|c|c|c|c|c|c|}
\hline MIS & $\begin{array}{l}\text { MIS } \\
\text { age } \\
\text { (ka) }\end{array}$ & $+/-$ & $\begin{array}{l}\text { Sea } \\
\text { level } \\
\text { (m) }\end{array}$ & $+/-$ & $\begin{array}{l}\text { Point Reyes } \\
\text { Terrace n\# } \\
\text { (Grove et } \\
\text { al.) } \\
\end{array}$ & $\begin{array}{l}\text { terraces } \\
\text { Mean } \\
\text { inner } \\
\text { edge } \\
\text { elevation } \\
\text { (m) }\end{array}$ & $\begin{array}{l}\text { Number } \\
\text { of data }\end{array}$ & $\begin{array}{l}\text { Uplift } \\
\text { rate } \\
\text { (m/ka) }\end{array}$ & $+/-$ & $\begin{array}{c}\text { Terrace n\# } \\
\text { (Grove et } \\
\text { al.) }\end{array}$ & $\begin{array}{l}\text { Mean } \\
\text { inner } \\
\text { edge } \\
\text { elevation } \\
(\mathrm{m}) \\
\end{array}$ & $\begin{array}{l}\text { Uplift } \\
\text { rate } \\
\text { (m/ka) }\end{array}$ & $+/-$ \\
\hline $5 a$ & 85 & 5 & -15 & 10 & 1 & 20.5 & 4 & 0.418 & 0.120 & & & & \\
\hline $5 e$ & 125 & 7 & 0 & 3 & 3 & 39 & 1 & 0.312 & 0.030 & 1 & 87 & 0.696 & 0.046 \\
\hline $7 e$ & 225 & 7 & 0 & 3 & 4 & 82.3 & 3 & 0.366 & 0.018 & 2 & 152 & 0.676 & 0.025 \\
\hline $9 c$ & 321 & 6 & 8 & 10 & 5 & 110.5 & 4 & 0.319 & 0.032 & 3 & 177 & 0.526 & 0.033 \\
\hline 11 & 404 & 6 & 8 & 10 & 6 & 149.5 & 2 & 0.350 & 0.025 & 4 & 220 & 0.525 & 0.026 \\
\hline 13 & 500 & 10 & 0 & 10 & 7 & 172.75 & 4 & 0.346 & 0.021 & & & & \\
\hline 15 & 570 & 10 & 0 & 10 & 8 & 205 & 3 & 0.360 & 0.019 & & & & \\
\hline 17 & 690 & 10 & -20 & 10 & 9 & 246 & 3 & 0.386 & 0.016 & & & & \\
\hline
\end{tabular}

Table 4. Point Reyes Peninsula terrace shoreline angle elevations and ages assigned from dating constraints and morphostratigraphy, reworked from GROVE et al. 2010.

\subsubsection{San Juan de Marcona, Peru}

San Juan de Marcona site is located along the Pacific coast of Peru $\left(15.3^{\circ} \mathrm{S}, 75.1^{\circ} \mathrm{W}\right.$, Figure 1). The area is uplifting ( $\sim 0.5 \mathrm{~mm} / \mathrm{a}$ uplift rate) following the subduction of the buoyant Nazca Ridge underneath (MACHARE \& ORTLIEB 1992; REGARD et al. 2010; REGARD et al. 2009; SAILLARD et al. 2011). The uplift is recorded by a marine terraces sequence up to $800 \mathrm{~m}$ (15 terraces up to $360 \mathrm{~m}$ ) above sea level (MACHARE \& ORTLIEB 1992), well preserved in the regional arid climate. It is carved into Paleozoic and Mesozoic igneous and metamorphic rocks (MACHARE \& ORTLIEB 1992). We use GPS topographic profiles produced during M. SAILLARD's Ph.D. thesis (2008). These data have a precision of $20 \mathrm{~cm}$. We only use three shore platform terrace profiles where the sequence is best exposed: near the Cerro El Huevo (two profiles) and near the Cerro Tres Hermanas (SAILLARD et al. 2011). Both geomorphic terrace succession (morphostratigraphy) and absolute dating through cosmogenic ${ }^{10} \mathrm{Be}$ ) lead to a robust chronostratigraphy where 7 terraces are allocated to the last four interglacial periods (MIS5 to MIS11); MIS5e terrace shoreline angle lies at $105 \mathrm{~m}$ and 80m, for Cerro El Huevo and Cerro Tres Hermanas, respectively (SAILLARD et al. 2011). The same authors provided measurement of terrace width; on the contrary, the presence of slope deposits makes slope measurements unconfident (SAILLARD et al. 2011) (Table 5).

\subsubsection{Altos de Talinay, Chile}

Altos de Talinay site $\left(30.9^{\circ} \mathrm{S}, 71.7^{\circ} \mathrm{W}\right.$, Figure 1) was chosen because it is the subject of a study with age determinations (SAILLARD et al. 2012; SAILLARD et al. 2009) and accurate GPS profiling (SAILLARD 2008). It is an uplifting peninsula with a sequence of 5 terraces up to $425 \mathrm{~m}$, cut into bedrock made of Devonian-Carboniferous metasediments and Triassic- 
Jurassic igneous complexes. The proposed chronostratigraphy encompasses terraces formed during MIS5, MIS7 and MIS9 highstands. In addition, ${ }^{10} \mathrm{Be}$ absolute dating revealed the absence of many terraces, between those formed during MIS9 and MIS17 (SAILLARD et al. 2010; SAILLARD et al. 2009). The uplift rate is variable from 0.1 to $1.2 \mathrm{~mm} / \mathrm{a}$; MIS5e shoreline angle elevation is $25 \pm 3 \mathrm{~m}$.

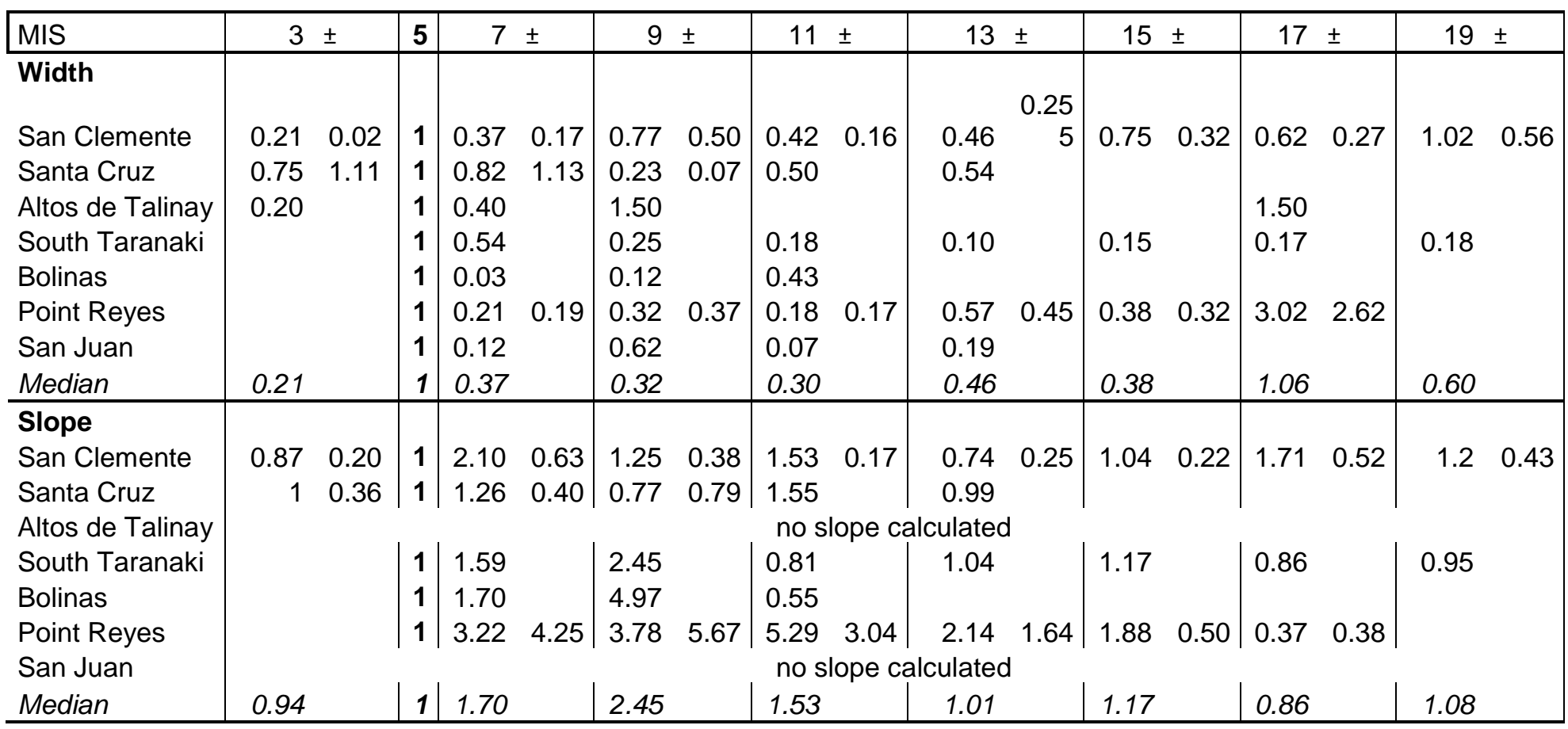

Table 5. Synthesis of the geometrical trend of the marine terraces within the selected sequences.

\subsubsection{South Taranaki, New-Zealand}

South Taranaki is a broad well-developed sequence of marine terraces occurring on the South Taranaki-Wanganui coastal plain in the southwest corner of the New Zealand North Island (Figure 1). The sequence developed into the Wanganui Basin made of $4800 \mathrm{~m}$ of Pliocene-Pleistocene shallow marine sediments. The sequence includes 11 terraces; it is more than $20 \mathrm{~km}$-wide and reaches more than $350 \mathrm{~m}$. Numerous dating constraints have been provided by a work by PILLANS (1983) with a schema of the terraces and overlying sediment geometry description. These dating constraints rely first on fission tracks dating on zircon and glass terrace from a 400 kyrs-old tephra lying over a terrace (PILLANS 1983). It has secondarily been used to calibrate amino-acid dating performed on younger terrace topping materials. Older terrace ages has been proposed considering a constant uplift rate (PILLANS 1983). The terraces are often covered by sediments, the thickness of which is schematized in PILLANS (1983). MIS5e is here at $\sim 70 \mathrm{~m}$; the uplift rate is $\sim 0.5 \mathrm{~mm} / \mathrm{a}$.

\subsubsection{Synthesis: reliability of the terrace sequence barcode}

We remind here that we call 'barcode' the signal constituted by alternating terraces more or less developed in a staircase sequence. First, one must note that the terrace numbers are generally low, thus power and presence indices are only significant for particularly "rich" sites. Figure 13A presents these indexes calculated on the basis of the entire dataset, even if 
statistically controlled by San Clemente and Santa Cruz observations (33 and 19 profiles, respectively, on a total of 62); an attempt to correct this bias by averaging the mean values for each of the sites is shown on Figure 13B. These indexes reveal that the absence of a terrace is quite common, and thus the barcode is generally incomplete.

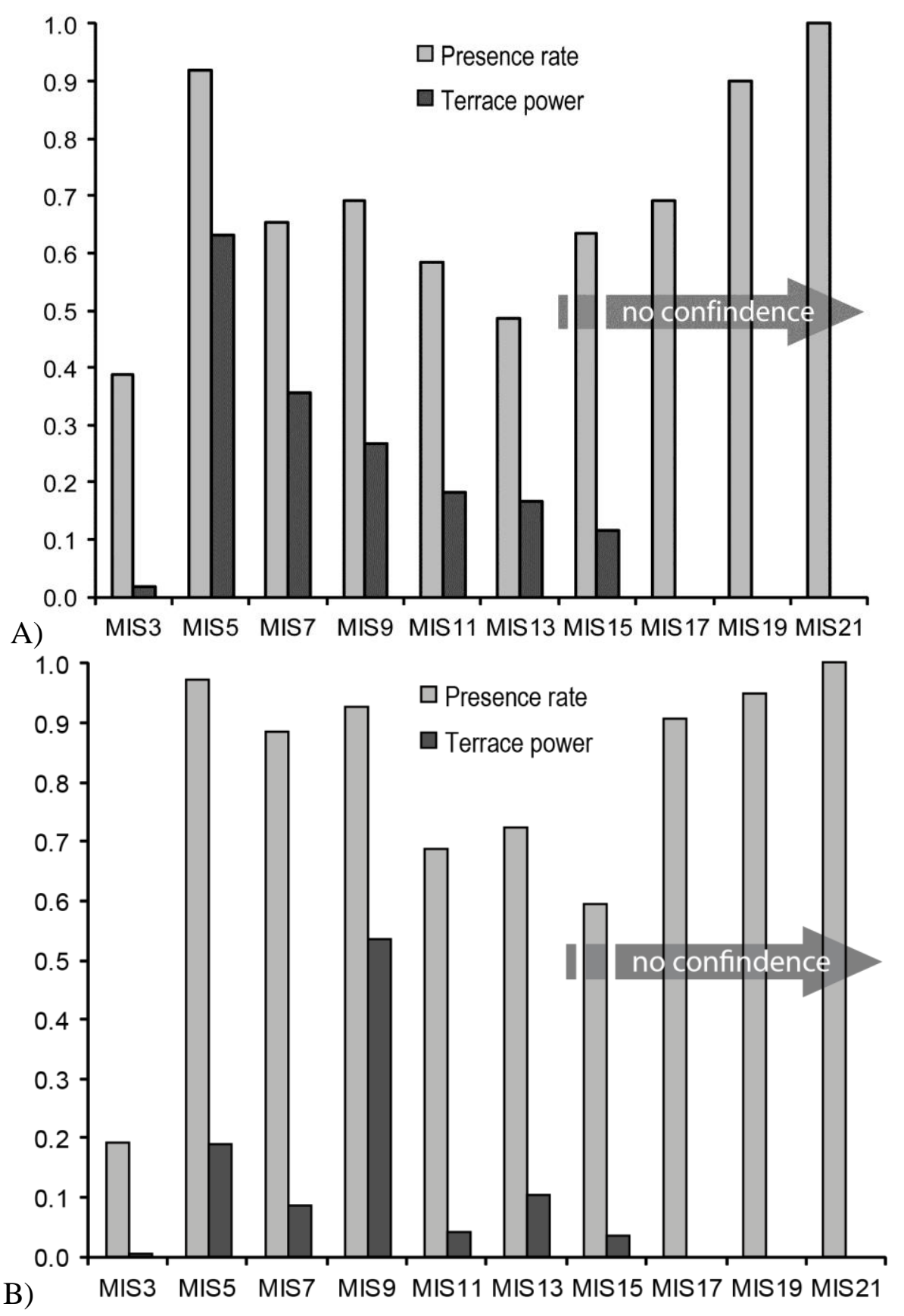

Figure 13. Presence and power indexes of our entire dataset. A) Calculated taking into account all the profiles. B) Calculated as the mean values for each of the sites: this provide an idea of the super-regional trends.

Our first observation is that the terrace associated with MIS5 highstand is by far the most often observed. Further, it is usually well individualized and widest than the other terraces in the Pleistocene sequence. We consider it as a good reference terrace. Moreover, it has been observed that many times its emplacement has probably removed previously formed terraces 
(terrace power $>0.6$, Figure 13). Nevertheless, the terrace correlated to MIS5e highstand is not always present (total presence rate of 92\%, Figure 13). In many coastal sites (see list in PEDOJA et al. 2011a) the MIS5e geomorphic record can be characterized by either a single or multiple (3) terraces with low elevation difference, being the younger wide terrace observed in profiles. Indeed, terraces lower than MIS5 one, for instance related to MIS3 or MIS1, are rare and narrow. In a single profile out of 62 a terrace younger than MIS5 is present while MIS5 terrace is absent.

MIS7 terrace is twice narrower than MIS5 one except in Santa Cruz. This terrace is always dipping more the one allocated to MIS5, even in Santa Cruz (Figure 12). This high dip could be due to that it is composed by 3 small terraces (MIS7a, MIS7c, and MIS7e). While terraces are less and less observed with their age (cf. ANDERSON et al. 1999), MIS7 terraces are less observed than MIS9 ones.

Terraces related to MIS9 are frequently preserved; the presence rates of such terraces reaches 69\%. In Santa Cruz and San Clemente, MIS9 dip is similar to the average MIS5 terrace dip, while it is dipping more than MIS5 terrace in the other studied sequences. MIS9 terrace width is variable: sometimes it exceeds half that of MIS5 terrace (San Clemente, San Juan de Marcona, Altos de Talinay), whereas it is clearly narrower in Santa Cruz, Bolinas, Point Reyes and South Taranaki, but comparable with younger and older terraces. MIS9 terrace is sometimes compound: composed by MIS9a and MIS9c subterraces.

The MIS11 terrace has a somewhat important presence rate (Figure 12). San Clemente and Santa Cruz datasets indicate a width of approximatively half that of MIS5, but in other places with the noticeable exception of Bolinas, it is much narrower (normalised width between 0.06 and 0.2). Its dip is higher than MIS5 terrace, except in South Taranaki and Bolinas; the inverse was postulated given that MIS5 terrace is compound (3 highstands: MIS5e, MIS5c and MIS5a) while MIS11 is characterized by a single noticeable highstand: MIS11c (MIS11a sea level highstand being low, cf. BINTANJA \& VAN DE WAL 2008; CAPUTO 2007).

MIS13 terrace is not very often observed (presence rate of less than 50\%). This is the highest terrace observed in most of the studied sites. Only in Point Reyes its dip is comparable to that of MIS5 terrace and its width is comparable to the width of the terrace immediately above or below it (i.e., terraces related to sea level highstands during MIS11 and MIS15).

Finally, our DEM analysis reveals that the uppermost terraces (formed during MIS15, MIS 17, and MIS19) in the sequences deserve more attention than in previous works. Their dips are similar to younger terraces and their width too. Moreover, they are sometimes much wider. It is the case for the inferred MIS17 terrace in Point Reyes and Altos de Talinay. In this latter site, higher terraces are not observed, thus we cannot rule out the fact that this could be a compound MIS17-MIS19 terrace. In San Clemente and South Taranaki, every interglacial is represented in the sequence; the uppermost terraces (allocated to MIS15 to 17) are either wider than or as wide as MIS11 and MIS13 terraces.

As there are doubts concerning ages for San Clemente and Santa Cruz terraces, it is necessary to check the sensitivity of our analysis to our scenario choice. First, it is noticeable that the ambiguity is never bigger than a period between 2 successive highstands; it appears for MIS9 or older highstands. Hence our conclusions for MIS1, 3, 5 and 7 remain the same. The $2^{\text {nd }}$ scenario for San Clemente leads to similar conclusions than the first one, except for the wider and less steep MIS17 terraces. Using the $2^{\text {nd }}$ scenario for Santa Cruz instead of the first one only affects MIS9 and 11 terraces: it results in quite similar conclusions as scenario 
1. Finally, our conclusions about the respective importance of MIS9 and MIS11 terraces discussed before remain similar whatever the scenario used.

\subsection{Possible implications at global scale}

First, our dataset emphasizes that the last interglacial period has left lots of remnants (as already emphasized by JOHNSON \& LIBBEY 1997; PEDOJA et al. 2011a). As this terrace is among the most recent ones, it is generally better preserved. Alternatively, it can be argued that current interglacial is incomplete and ocean forcing has not had enough time to remove it. Opposed arguments are the fact that sometimes terraces at lower elevations have not been eroded yet, or that current interglacial is close to its end (e.g., GIACCIO et al. 2015).

Second, our dataset indicates that MIS9 (that can be compound) was prone to leave terraces whereas MIS11 is not characterized by notably large terraces, as proposed in former works (BOWEN 2010; e.g., MASSON-DELMOTTE et al. 2010; ORTLIEB et al. 1996; ORTLIEB et al. 2003; PAST INTERGLACIALS WORKING GROUP OF PAGES 2016; REGARD et al. 2010; ROHLING et al. 2010; SIDDALL et al. 2006). Interestingly, the width figure (Figure 12) confirms that usually the MIS5 terrace is the most developed terrace (JOHNSON \& LIBBEY 1997; PEDOJA et al. 2011a). Similarly, the lowermost terrace is always a narrow one (Figure 12); it probably corresponds to the current interglacial (MIS1) and is beyond the scope of this study. Next, there is no clear information, except that MIS13 and MIS17 terraces appear to be wider than the others; on the other hand, MIS11 seems to lead to narrow terraces, whereas it is thought to correspond to a very specific period regarding to terrace formation and sea level. It is particularly noticeable that isotopic records argue for a predominant interglacial climate during MIS11 whereas MIS15, 17 and 19 are described as weak interglacials (MASSON-DELMOTTE et al. 2010) or short-lasting compared to MIS11 (PAST INTERGLACIALS WORKING GROUP OF PAGES 2016). Our dataset shows, instead, an opposite trend: MIS15, 17 and 19 are more prominent than MIS11.

Terrace shape (i.e., width and slope) is likely dependent on the duration and sea level history during a sea level highstand (e.g., BRADLEY \& GRIGGS 1976): shore platform marine terraces are theoretically wider when the highstand lasts for a longer time. On the other hand, it is not easy to decipher what caused the current terrace slope. It depends on the original slope and later terrace degradation. The initial slope is the result of a combination of factors like the ratio between sea-level fluctuations and uplift rate (Figure 14), wave abrasion efficiency, etc. Terrace degradation through riser smoothing (relief diffusion) must lead to slope to increase or decrease for terraces and scarps, respectively (e.g., ANDERSON et al. 1999). The later effect only affects a narrow fringe of the terrace, near its boundaries. It has hence only little influence for terrace width conservation and has not been clearly observed in the present dataset.

We choose to work on sequences of marine terraces carved in homogeneous lithology. Factors like lithology or paleogeography may not have changed during the terrace sequence formation. Indeed, the strandlines defined by the terrace risers are quite straight, showing that the main coast figure has little changed during the time span of terrace sequence formation. It probably results in a comparable exposure to ocean swell and tides. If we exclude the uplift rate, the remaining factors that can modify the terrace record consist in interglacial specificities, probably similar all over the world with the exception of periglacial areas where deglaciation sea level history is different (e.g., WOODROFFE \& HORTON 2005). The 
dataset presented here is a first attempt to interpret wave cut terrace geometry in terms of paleoclimate and sea-level. We suspect in-sequence terrace geometry has strong potential.

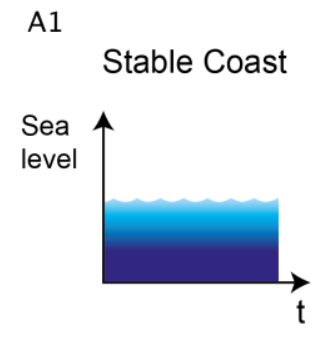

B1

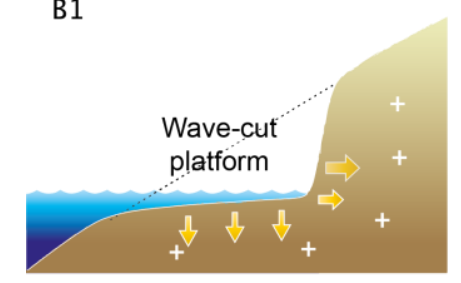

$\mathrm{C} 1$

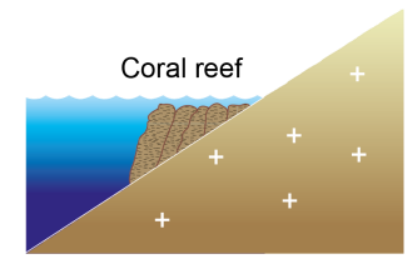

A2

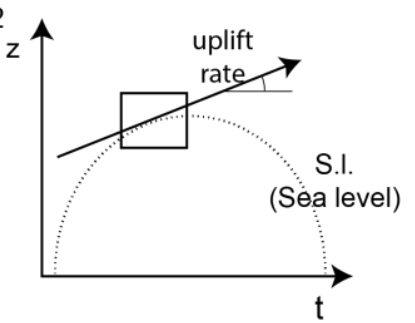

B2

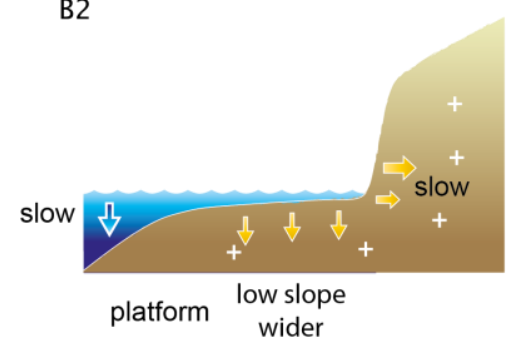

$\mathrm{C} 2$

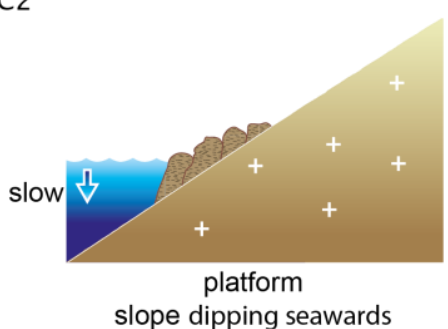

A3

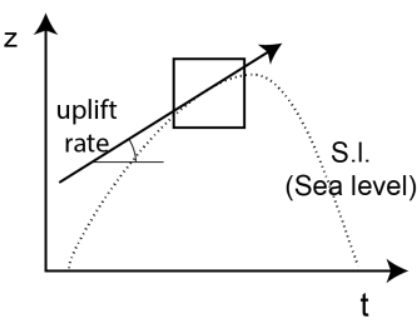

B3

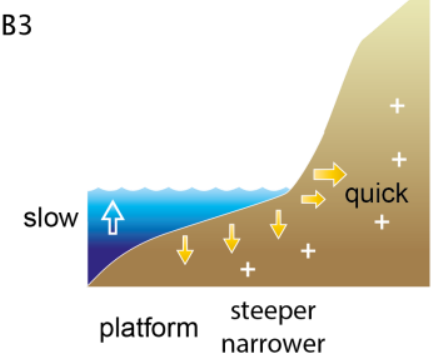

C3

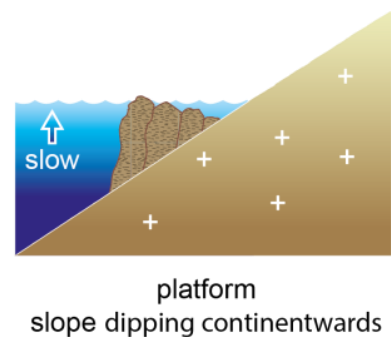

Figure 14. Shoreline response to varying sea level. Line A: 3 relative sea-level histories: (A1) stable, (A2) history for which rising and dropping sea occurs with the same characteristic time, (A3) history for which the relative sea level rise slower than its subsequent drop (modified after Muhs et al. 2002). Line B: consequence for a shore platform development, line C: consequence for reef shore development. Note the difference in the resulting platform slope.

Coral reef terraces are widely distributed on earth and how they develop in function of sea level is well known (CHAPPELL 1974; MONTAGGIONI \& BRAITHWAITE 2009; NEXER et al. 2015; PIRAZZOLI et al. 1991). Thus they deserve a comparison with the shore platform terraces on which our study focusses. The main difference between them is the mode of formation: shore platform terraces are erosional while coral reef terraces are constructional (even if they sometimes can be reworked by erosion like a shore platform terrace). Hence, the main factors responsible for terrace geometry have not the same effect for the two terrace kinds. These effects are tentatively schematized on Figure 14 and are listed below.

(1) Sea level highstand duration. This has probably a similar positive effect on terrace width.

(2) Sea level variations. The main difference between coral reef terraces and shore platform terraces is that under a stable sea level a shore platform progresses towards the continent whereas a reef builds oceanwards. Hence, if sea-level is slowly decreasing at the end of the highstand, the shore platform is uniformly downwearing leading to a gently dipping platform whereas the reef outer edge will propagate 
downwards following sea level, resulting in a steep slope (MASSE \& MONTAGGIONI 2001).

(3) Climate effect. The different highstands should not have had the same climatic features (MASSON-DELMOTTE et al. 2010). The main climatic factors are waves and water temperature. They may have a complex effect, different for shore platform and reef formation (Figure 14).

\section{Conclusion}

We investigated if the geometry of the succesive shore platform terrace within a sequence keeps information about the highstands during which they formed. We base part of our conclusions on newly proposed indexes for in-sequence quantification: presence rate $\left(P_{r}\right)$ and power $\left(P_{i}\right)$ indexes. Some first order observations can be made, despite the important variability in space of the marine terrace record. This work emphasizes that the MIS5 terrace is usually the best observed in the landscape: it is the widest and the most frequently preserved. At our selected sites that are globally distributed, a novel observation is that other terraces are also well recorded as the MIS7, MIS9 ( $2^{\text {nd }}$ most frequent one); older terraces formed during MIS15, MIS17 and MIS19 are also frequently developed and must not be missed in spite of their frequent degradation. In turn, the MIS11 terraces are not preeminent in the record, which confronts with the results presented in former works (BOWEN 2010; e.g., MASSON-DELMOTTE et al. 2010; ORTLIEB et al. 1996; ORTLIEB et al. 2003; PAST INTERGLACIALS WORKING GROUP OF PAGES 2016; REGARD et al. 2010; ROHLING et al. 2010; SIDDALL et al. 2006).

However, additional efforts must be made for future work leads to information regarding past interglacial climatology or duration. The most critical point in such studies is dating. Indeed, this work shows the complexity of differentiating some terraces on the unique basis of their elevation and morphostratigraphic succession. This point is made more crucial again when a given terrace may have been completely removed (cf. the presence rate showed in Figure 8), and also by the dependence on the number of terraces recorded in function of the uplift rate and sea level history (CAPUTO 2007): for example MIS8c terrace is probably observed in Santa Cruz.

A second point is the slope. Working with slope requires very precise DEM, and could be falsified by colluvial sediments mantling the terraces as in South Taranaki (PILLANS 1983). Also, the effect of the initial slope before shore platform carving deserves further exploration (e.g., MARTINOD et al. 2016).

Future works must take into account MIS substages (i.e., MIS5a, MIS5c and MIS5e), as the current data do not allow this exploration yet. They also may focus on other types of marine terraces like coral reef terraces: the comparison of both dataset may provide insights into inner-MIS sea level variations.

\section{Acknowledgements}

This study was conducted within an INSU/SHOM reliefs de la Terre program "erosion of rocky coasts" (PI V. Regard) and additional funding by University of Toulouse (UPS/OMP). We thank J. Martinod, S. Carretier, L. Husson, T. Dewez, D. Chardon and G. Hérail for fruitful discussions. We thank C. Cavaré-Hester for designing Figure 14. 


\section{References}

ALEXANDER, C. S. (1953): The marine and stream terraces of the Capitola- Watsonville area. California Univ. Pubs. Geography 10. S. 1-44.

ANDERSON, R. S., DENSMORE, A. L. \& ELLIS, M. A. (1999): The generation and degradation of marine terraces. Basin Research 11. (Heft 1). S. 7-19.

BINTANJA, R. \& VAN DE WAL, R. S. W. (2008): North American ice-sheet dynamics and the onset of 100,000-year glacial cycles. Nature 454. (Heft 7206). S. 869-872.

BOWEN, D. Q. (2010): Sea level similar to 400000 years ago (MIS 11): analogue for present and future sea-level? Climate of the Past 6. (Heft 1). S. 19-29.

BRADLEY, W. C. \& ADDICOTT, W. O. (1968): Age of First Marine Terrace Near Santa Cruz, California. Geological Society of America Bulletin 79. (Heft 9). S. 1203-1210.

BRADLEY, W. C. \& GRIGGS, G. B. (1976): Form, genesis, and deformation of some central California wave-cut platforms. Bull Geol. Soc. Am. 87. S. 433-449.

BRANNER, J. C., NEWSOM, J. F. \& ARNOLD, R. (1909): Santa Cruz folio. o. O.

BROWN, E. T. \& BOURLES, D. L. (2002): Use of a new Be-10 and Al-26 inventory method to date marine terraces, Santa Cruz, California, USA: Comment. Geology 30. (Heft 12). S. $1147-1148$.

CAPlAIN, B., ASTRUC, D., REGARD, V. \& MOULIN, F. Y. (2011): Cliff retreat and sea bed morphology under monochromatic wave forcing: Experimental study. Comptes Rendus Geoscience 343. (Heft 7). S. 471-477.

CAPUTO, R. (2007): Sea-level curves: Perplexities of an end-user in morphotectonic applications. Global And Planetary Change 57. (Heft 3-4). S. 417-423.

CHAPPELL, J. (1974): The Geomorphology and Evolution of Small Valleys in Dated Coral Reef Terraces, New Guinea. The Journal of Geology 82. (Heft 6). S. 795-812.

CRITTENDEN, R. \& MUHS, D. (1986): Cliff-Height and Slope-Angle Relationships in a Chronosequence of Quaternary Marine Terraces, San-Clemente-Island, California. Zeitschrift für Geomorphologie 30. (Heft 3). S. 291-301.

CUTLER, K. B., EDWARDS, R. L., TAYLOR, F. W., CHENG, H., ADKINS, J., GALLUP, C. D., CUTLER, P. M., BURR, G. S. \& BLOOM, A. L. (2003): Rapid sea-level fall and deep-ocean temperature change since the last interglacial period. Earth and Planetary Science Letters 206. (Heft 3-4). S. 253-271.

GIACCIO, B., REGATTIERI, E., ZANCHETTA, G., NOMADE, S., RENNE, P. R., SPRAIN, C. J., DRYSDALE, R. N., TZEDAKIS, P. C., MESSINA, P., SCARDIA, G., SPOSATO, A. \& BASSINOT, F. (2015): Duration and dynamics of the best orbital analogue to the present interglacial. Geology. S. G36677.1. 
GROVE, K., SKLAR, L. S., SCHERER, A. M., LEE, G. \& DAVIS, J. (2010): Accelerating and spatially-varying crustal uplift and its geomorphic expression, San Andreas Fault zone north of San Francisco, California. Tectonophysics 495. (Heft 3-4). S. 256-268.

HENRY, H., REGARD, V., PEDOJA, K., HUSSON, L., MARTINOD, J., WITT, C. \& HEURET, A. (2014): Upper Pleistocene uplifted shorelines as tracers of (local rather than global) subduction dynamics. Journal of Geodynamics 78. S. 8-20.

JARA-MUÑOZ, J. \& MELNICK, D. (2015): Unraveling sea-level variations and tectonic uplift in wave-built marine terraces, Santa María Island, Chile. Quaternary Research 83. (Heft 1). S. 216-228.

JEDOUI, Y., REYSS, J. L., KALLEL, N., MONTACER, M., BEN ISMAIL, H. \& DAVAUD, E. (2003): U-series evidence for two high Last Interglacial sea levels in southeastern Tunisia. Quaternary Science Reviews 22. (Heft 2-4). S. 343-351.

JOHNSON, M. E. \& LIBBEY, L. K. (1997): Global review of Upper Pleistocene (substage 5e) rocky shores: Tectonic segregation, substrate variation, and biological diversity. Journal of Coastal Research 13. (Heft 2). S. 297-307.

KENNEDY, G. L., VEDDE, J. G., PETERSON, E., WRIGHT, R. W., BELKNAP, D. F., LAJOIE, K. R., KVENVOLDEN, K. A., ADDICOTT, W. O. \& WEHMILLER, J. F. (1977): Correlation and chronology of Pacific Coast marine terrace deposits of continental United States by fossil amino acid stereochemistry technique, evaluation, relative ages, kinetic model ages, and geologic implications.

LAJOIE, K. R. (1986): Coastal Tectonics. Active Tectonics Impact on Society.

LAJOIE, K. R., PONTI, D. J., POWELL II, C. L., MATHIESON, S. A. \& SARNAWOJCICKI, A. M. (1991): Emergent marine strandlines and associated sediments, coastal California; a record of Quaternary sea-level fluctuations, vertical tectonic movements, climatic changes, and coastal processes. Quaternary nonglacial geology: Conterminous U.S. S. 190-203.

LAWSON, A. C. (1893): The post-Pliocene diastrophism of the coast of southern California. California Univ. Dept. Geol. Sci. Bull. 1. (Heft 115-160).

LUDWIG, K., MUHS, D., SIMMONS, K. \& MOORE, J. (1992): Sr-Isotope Record of Quaternary Marine Terraces on the California Coast and Off Hawaii. Quaternary Research 37. (Heft 3). S. 267-280.

MACHARE, J. \& ORTLIEB, L. (1992): Plio-Quaternary vertical motions and the subduction of the Nazca Ridge, central coast of Peru. Tectonophysics 205. (Heft 1-3). S. 97.

MARQUARDT, C., LAVENU, A., ORTLIEB, L., GODOY, E. \& COMTE, D. (2004): Coastal neotectonics in Southern Central Andes: uplift and deformation of marine terraces in Northern Chile (27 degrees S). Tectonophysics 394. (Heft 3-4). S. 193-219.

MARTINOD, J., REGARD, V., RIQUELME, R., AGUILAR, G., GUILLAUME, B., CARRETIER, S., CORTÉS-ARANDA, J., LEANNI, L. \& HÉRAIL, G. (2016): Pleistocene uplift, climate and morphological segmentation of the Northern Chile coasts $\left(24^{\circ} \mathrm{S}-32^{\circ} \mathrm{S}\right)$ : Insights from cosmogenic 10Be dating of paleoshorelines. Geomorphology 274. S. 78-91. 
MASSE, J. \& MONTAGGIONI, L. (2001): Growth history of shallow-water carbonates: control of accommodation on ecological and depositional processes. International Journal of Earth Sciences 90. (Heft 2). S. 452-469.

MASSON-DELMOTTE, V., STENNI, B., POL, K., BRACONNOT, P., CATTANI, O., FALOURD, S., KAGEYAMA, M., JOUZEL, J., LANDAIS, A., MINSTER, B., BARNOLA, J. M., CHAPPELLAZ, J., KRINNER, G., JOHNSEN, S., ROTHLISBERGER, R., HANSEN, J., MIKOLAJEWICZ, U. \& OTTO-BLIESNER, B. (2010): EPICA Dome C record of glacial and interglacial intensities. Quaternary Science Reviews 29. (Heft 1-2). S. 113-128.

MELNICK, D., BOOKHAGEN, B., STRECKER, M. R. \& ECHTLER, H. P. (2009): Segmentation of megathrust rupture zones from fore-arc deformation patterns over hundreds to millions of years, Arauco peninsula, Chile. Journal of Geophysical Research 114. (Heft B1).

MERIFIELD, P. M., LAMAR, D. L. \& STOUT, M. L. (1971): Geology of Central San Clemente Island, California. Geological Society of America Bulletin 82. S. 1989-1994.

MONTAGGIONI, L. F. \& BRAITHWAITE, C. J. R. (2009): Quaternary Coral Reef Systems: History, development processes and controlling factors. o. O. $550 \mathrm{~S}$.

MUHS, D. \& SZABO, B. (1982): Uranium-Series Age of the Eel-Point Terrace - SanClemente Island, California. Geology 10. (Heft 1). S. 23-26.

MUHS, D. R. (1983): Quaternary Sea Level Events on Northern San Clemente Island, California. Quaternary Research 20. S. 322-341.

MUHS, D. R., SIMMONS, K. R., KENNEDY, G. L. \& ROCKWELL, T. K. (2002): The last interglacial period on the Pacific Coast of North America: Timing and paleoclimate. GSA Bulletin 114. (Heft 5). S. 569-592.

MURRAY-WALLACE, C. V. \& WOODROFFE, C. D. (2014): Quaternary sea-level changes: a global perspective. 1. publ. Cambridge. 484 S.

NEXER, M., AUTHEMAYOU, C., SCHILDGEN, T., HANTORO, W. S., MOLLIEX, S., DELCAILlAU, B., PEDOJA, K., HUSSON, L. \& REGARD, V. (2015): Evaluation of morphometric proxies for uplift on sequences of coral reef terraces: A case study from Sumba Island (Indonesia). Geomorphology 241. S. 145-159.

O'LEARY, M. J., HEARTY, P. J., THOMPSON, W. G., RAYMO, M. E., MITROVICA, J. X. \& WEBSTER, J. M. (2013): Ice sheet collapse following a prolonged period of stable sea level during the last interglacial. Nature Geoscience advance online publication.

ORTLIEB, L., GUZMAN, N. \& MARQUARDT, C. (2003): A Longer-Lasting and Warmer Interglacial Episode During Isotopic Stage 11: Marine Terrace Evidence in Tropical Western Americas. Earth's Climate and Orbital Eccentricity, the Marine Isotope Stage 11 Question. S. $157-180$.

ORTLIEB, L., ZAZO, C., GOY, J. L., HILlAIRE-MARCEL, C., GHALEB, B. \& COURNOYER, L. (1996): Coastal deformation and sea-level changes in the northern Chile subduction area (23 degrees S) during the last $330 \mathrm{ky}$. Quaternary Science Reviews 15. (Heft 8-9). S. 819-831. 
PAGE, B. M. \& HOLMES, C. N. (1945): Geology of the bituminous sandstone deposits near Santa Cruz, Santa Cruz County, California. o. O.

PAST INTERGLACIALS WORKING GROUP OF PAGES (2016): Interglacials of the last 800,000 years. Reviews of Geophysics. S. 2015RG000482.

PEDOJA, K., HUSSON, L., JOHNSON, M. E., MELNICK, D., WITT, C., POCHAT, S., NEXER, M., DELCAILlAU, B., PINEGINA, T., POPRAWSKI, Y., AUTHEMAYOU, C., ELLIOT, M., REGARD, V. \& GARESTIER, F. (2014): Coastal staircase sequences reflecting sea-level oscillations and tectonic uplift during the Quaternary and Neogene. EarthScience Reviews 132. S. 13-38.

PEDOJA, K., HUSSON, L., REGARD, V., COBBOLD, P. R., OSTANCIAUX, E., JOHNSON, M. E., KERSHAW, S., SAILLARD, M., MARTINOD, J., FURGEROT, L., WEILL, P. \& DELCAILLAU, B. (2011a): Relative sea-level fall since the last interglacial stage: Are coasts uplifting worldwide? Earth-Science Reviews 108. (Heft 1-2). S. 1-15.

PEDOJA, K., ORTLIEB, L., DUMONT, J. F., LAMOTHE, M., GHALEB, B., AUCLAIR, M. \& LABROUSSE, B. (2006): Quaternary coastal uplift along the Talara Arc (Ecuador, Northern Peru) from new marine terrace data. Marine Geology 228. (Heft 1-4). S. 73-91.

PEDOJA, K., REGARD, V., HUSSON, L., MARTINOD, J., GUILLAUME, B., FUCKS, E., IGLESIAS, M. \& WEILL, P. (2011b): Uplift of quaternary shorelines in eastern Patagonia: Darwin revisited. Geomorphology 127. (Heft 3-4). S. 121-142.

PERG, L. A., ANDERSON, R. S. \& FINKEL, R. C. (2001): Use of a new Be-10 and Al-26 inventory method to date marine terraces, Santa Cruz, California, USA. Geology 29. (Heft 10). S. 879-882.

PERG, L. A., ANDERSON, R. S. \& FINKEL, R. C. (2002): Use of a new Be-10 and Al-26 inventory method to date marine terraces, Santa Cruz, California, USA: Reply. Geology 30. (Heft 12). S. 1148-1148.

PILLANS, B. (1983): Upper Quaternary marine terrace chronology and deformation, South Taranaki, New Zealand. Geology 11. S. 292-297.

PIRAZZOLI, P. A., RADTKE, U., HANTORO, W. S., JOUANNIC, C., HOANG, C. T., CAUSSE, C. \& BEST, M. B. (1991): Quaternary Raised Coral-Reef Terraces on Sumba Island, Indonesia. Science 252. (Heft 5014). S. 1834-1836.

PIRAZZOLI, P. A., RADTKE, U., HANTORO, W. S., JOUANNIC, C., HOANG, C. T., CAUSSE, C. \& BOREL BESTH, M. (1993): A one million-year-long sequence of marine terraces on Sumba Island, Indonesia. Marine Geology 109. S. 221-236.

REGARD, V., DEWEZ, T., BOURLÈS, D. L., ANDERSON, R. S., DUPERRET, A., COSTA, S., LEANNI, L., LASSEUR, E., PEDOJA, K. \& MAILLET, G. M. (2012): Late Holocene seacliff retreat recorded by $10 \mathrm{Be}$ profiles across a coastal platform: Theory and example from the English Channel. Quaternary Geochronology 11. S. 87-97.

REGARD, V., LAGNOUS, R., ESPURT, N., DARROZES, J., BABY, P., RODDAZ, M., CALDERON, Y. \& HERMOZA, W. (2009): Geomorphic evidence for recent uplift of the 
Fitzcarrald Arch (Peru): A response to the Nazca Ridge subduction. Geomorphology 107. (Heft 3-4). S. 107-117.

REGARD, V., SAILlARD, M., MARTINOD, J., AUDIN, L., CARRETIER, S., PEDOJA, K., RIQUELME, R., PAREDES, P. \& HÉRAIL, G. (2010): Renewed uplift of the Central Andes Forearc revealed by coastal evolution during the Quaternary. Earth and Planetary Science Letters 297. (Heft 1-2). S. 199-210.

RODE, K. (1930): Geomorphogenie des Ben Lomond (Kalifornien), eine Studie über Terrassenbildung durch marine Abrasion. Zeitschift für Geomorphologie 5. S. 16-78.

ROHLING, E. J., BRAUN, K., GRANT, K., KUCERA, M., ROBERTS, A. P., SIDDALL, M. \& TROMMER, G. (2010): Comparison between Holocene and Marine Isotope Stage-11 sea-level histories. Earth and Planetary Science Letters 291. (Heft 1-4). S. 97-105.

ROSENBLOOM, N. A. \& ANDERSON, R. S. (1994): Hillslope and channel evolution in a marine terraced landscape, Santa Cruz, California. Journal of Geophysical Research: Solid Earth 99. (Heft B7). S. 14013-14029.

SAILLARD, M. (2008): Dynamique du soulèvement côtier Pléistocène des Andes centrales : Etude de l'évolution géomorphologique et datations (10Be) de séquences de terrasses marines (Sud Pérou - Nord Chili). Dissertation, Université de Toulouse.

SAILLARD, M., HALL, S. R., AUDIN, L., FARBER, D. L., HÉRAIL, G., MARTINOD, J., REGARD, V., FINKEL, R. C. \& BONDOUX, F. (2009): Non-steady long-term uplift rates and Pleistocene marine terrace development along the Andean margin of Chile $\left(31^{\circ} \mathrm{S}\right)$ inferred from 10Be dating. Earth and Planetary Science Letters 277. (Heft 1-2). S. 50.

SAILlARD, M., HALL, S. R., AUDIN, L., FARBER, D. L., MARTINOD, J., REGARD, V., PEDOJA, K. \& HÉRAIL, G. (2010): Reply to a Comment on "Non-steady long-term uplift rates and Pleistocene marine terrace development along the Andean margin of Chile $\left(31^{\circ} \mathrm{S}\right)$ inferred from 10Be dating" by M. Saillard, S.R. Hall, L. Audin, D.L. Farber, G. Hérail, J. Martinod, V. Regard, R.C. Finkel. and F. Bondoux [Earth Planet. Sci. Lett. 277 (2009) 5063]. Earth and Planetary Science Letters 296. (Heft 3-4). S. 506-509.

SAILLARD, M., HALL, S. R., AUDIN, L., FARBER, D. L., REGARD, V. \& HÉRAIL, G. (2011): Andean coastal uplift and active tectonics in southern Peru: 10Be surface exposure dating of differentially uplifted marine terrace sequences (San Juan de Marcona, $~ 15.4^{\circ} \mathrm{S}$ ). Geomorphology 128. (Heft 3-4). S. 178-190.

SAILlARD, M., RIOTTE, J., REGARD, V., VIOLETTE, A., HÉRAIL, G., AUDIN, L. \& RIQUELME, R. (2012): Beach ridges U-Th dating in Tongoy bay and tectonic implications for a peninsula-bay system, Chile. Journal of South American Earth Sciences 40. (Heft 0). S. 77-84.

SIDDALL, M., CHAPPELL, J. \& POTTER, E.-K. (2006): Eustatic Sea Level During Past Interglacials. The climate of past interglacials. S. 75-92.

STEPHENSON, W. J. \& KIRK, R. M. (2000a): Development of shore platforms on Kaikoura Peninsula, South Island, New Zealand - Part one: The role of waves. Geomorphology 32. (Heft 1-2). S. 21-41. 
STEPHENSON, W. J. \& KIRK, R. M. (2000b): Development of shore platforms on Kaikoura Peninsula, South Island, New Zealand - II: The role of subaerial weathering. Geomorphology 32. (Heft 1-2). S. 43-56.

THOMPSON, W. G. \& GOLDSTEIN, S. L. (2006): A radiometric calibration of the SPECMAP timescale. Quaternary Science Reviews 25. (Heft 23-24). S. 3207-3215.

TRENHAILE, A. S. (2000): Modeling the development of wave-cut shore platforms. Marine Geology 166. (Heft 1-4). S. 163.

TRENHAILE, A. S. (2002): Rock coasts, with particular emphasis on shore platforms. Geomorphology 48. (Heft 1-3). S. 7.

WARD, S. N. \& VALENSISE, G. (1996): Progressive growth of San Clemente Island, California, by blind thrust faulting: implications for fault slip partitioning in the California Continental Borderland. Geophysical Journal International 126. S. 712-734.

WOODROFFE, S. A. \& HORTON, B. P. (2005): Holocene sea-level changes in the IndoPacific. Journal Of Asian Earth Sciences 25. (Heft 1). S. 29-43. 